\title{
Morphology, bioacoustics and phylogeography of the Isophya major group (Orthoptera: Tettigoniidae: Phaneropterinae): A species complex occurring in Anatolia and Cyprus
}

\author{
Hasan SEVGİlí ${ }^{1}$, Battal ÇIPLAK ${ }^{2 *}, K_{\text {laus Gerhard HELlER }}^{3}$ and Ali DEMİRSOY ${ }^{4}$ \\ ${ }^{1}$ Department of Biology, Faculty of Art \& Science, Harran University Şanlıurfa, Turkey \\ ${ }^{2}$ Department of Biology, Faculty of Art \& Science, Akdeniz University 07058 Antalya, Turkey \\ ${ }^{3}$ Grillenstieg 18, 39120 Magdeburg, Germany \\ ${ }^{4}$ Department of Biology, Faculty of Science, Hacettepe University Ankara, Turkey
}

Key words. Orthoptera, Phaneropterinae, Isophya, I. major, I. mavromoustakisi, I. mersinensis sp. n., I. salmani sp. n., biogeography, Anatolia, Cyprus, Turkey, Eastern Mediterranean

\begin{abstract}
The species of the Isophya major-group (Orthoptera: Tettigoniidae: Phaneropterinae), are reviewed. I. major Brunner von Wattenwyl and I. mavromoustakisi Uvarov are redescribed. Two new species are described; Isophya mersinensis Sevgili \& Çıplak sp. n. and Isophya salmani Sevgili \& Heller sp. n. from south Anatolia. Illustrations of morphology and male calling song are provided and a detailed comparison of the four species in the group is presented. We conclude that these four species constitute a natural group in sharing male cerci with two or more denticles not ordered in a line, a character unique to this species group within the genus. From an evaluation of their morphology and song characteristics, relationships among the species in the group are $I$. major + (I. mersinensis sp. n. + (I. salmani + I. mavromoustakisi). Based on the the distribution pattern and habitat preference, we concluded that the division of I. salmani and I. mavromoustakisi was a vicariant event resulting from the separation of Cyprus and Anatolia due to reflooding of the Mediterranean after the Messinian salinity crisis at the beginning of the Pliocene, around 5 My ago.
\end{abstract}

\section{INTRODUCTION}

Isophya Brunner von Wattenwyl (Orthoptera: Tettigoniidae) is one of the most speciose genera of the subfamily Phaneropterinae, including more than 90 species (Bei-Bienko, 1954; Karabağ, 1958; Naskrecki et al., 2004; Harz, 1969; Heller, 1988; Heller et al., 1998, 2004; Çıplak et al., 2002; Sevgili \& Heller, 2003, Sevgili, 2003). The range of the genus extends from Central Europe (except for one species in the Pyrenées and southern France) to Iran in a west-east direction and from Central Europe/Central Asia to Levant in a north-south direction. However, most species are concentrated around the Black Sea basin, mainly in the Balkans, Anatolia and south-west Caucasus, with few species in the remaining parts of its range (La Greca, 1999). Importantly, most of the species show a local distribution restricted to some particular topography. More than one-third of the known species of Isophya were reported from Turkey (Çıplak et al., 2002), which is considered to be the radiation centre for this genus (La Greca, 1999). However, there is almost no modern study of the Anatolian species of the genus although the species in this area need be studied in detail.

Most species of the genus were originally described as morphospecies, though morphology is a poor character source for identification of Isophya species (Bei-Bienko, 1954). On the other hand, as these bush-crickets sing (mostly duetts), their songs can serve as an important tool for defining interbreeding units and testing "species hypothesis" according to modern species concepts (Howard \& Berlocher, 1998; Wheeler \& Meier, 2000). That's why in recent studies of species of Isophya (Ingrisch, 1991; Orci et al., 2001; Heller et al., 2004) most descriptions and diagnostic morphology are provided along with information on male calling songs or female responses. However, the song characteristics of the majority of Isophya species, especially those that occure outside Europe, are unknown. This hampers researchers in determining phylogenetic or biogeographic patterns and in solving of taxonomic problems. Thus, groups of related species in the genus are still not defined. Similarly, the phylogeny and biogeography of the genus are poorly studied.

Isophya major was first described by Brunner von Wattenwyl from specimens collected from Kyulek (Gülek pass) in the Cilician Taurus and a female from Cyprus (Brunner von Wattenwyl, 1878). However, the Cyprian specimen was later described as a different species, Isophya mavromoustakisi, and considered to be a sister species of I. major by Uvarov (1936). Later, these two species were occasionally mentioned in check-lists or regional faunal studies based on the original descriptions or with some additional material from different localities (Ramme, 1951; Karabağ, 1958; Mařan, 1958; Harz, 1969; Karabağ et al., 1981; Naskrecki \& Ünal 1995; Ünal, 1997, 1999, 2004). In spite of its importance for the taxonomy of the group, there is no song record for these species.

\footnotetext{
* Corresponding author; e-mail: ciplak@akdeniz.edu.tr
} 
During our recent studies of previously and newly collected material, and song records, it become apperent that Isophya major is not a single species, but a species complex including two new species; Isophya mersinensis Sevgili \& Çıplak sp. n. and I. salmani Sevgili \& Heller sp. n. which are described here. The group has an interesting distribution pattern, occurring in Central/Mediterranean Anatolia and Cyprus, two areas that were isolated from each other by the reflooding of the Mediterranean in early Pliocene (Kempler, 1998; Robertson, 1998). Further, these species seem to prefer different altitudes. In this study we describe two new species and redescribe Isophya major and I. mavromoustakisi on the basis of morphology and male calling song, provide relevant illustrations and conclusions about relationships, and biogeography of the species group.

\section{MATERIAL AND METHODS}

Specimens collected during the field studies were prepared as dry museum material by standard methods. Figures and measurements were obtained using a digital camera or a camera lucida attached to a stereo microscope. Terminology for morphology mainly follows Uvarov (1936), Ramme (1951) and BeiBienko (1954).

Specimens examined during this study are deposited in Hacettepe University, Department of Biology, Ankara (HUZOM), Collection of Biology Department in Ankara University, Ankara-Turkey (ABDA), Collection of Plant Protection Department in Ankara (AZME), Akdeniz University, Department of Biology, Zoological Museum, Antalya, Turkey (AUZM), The Natural History Museum, London (BMNH), Museum für Naturkunde, Berlin (ZMHB), Naturhistorisches Museum in Wien (NHMW) and personal collection of K.G. Heller in Magdeburg, Germany $(\mathrm{CH})$. The type material of some species was not available, but photographs of the relevant parts were obtained from SysTax, DORSA and OSF2. For electron microscopy, the left forewing was removed and transferred to absolute ethanol for at least $18 \mathrm{~h}$, then air dried and mounted on a microscope stub.

Song records were made with a Sony Cassette-Recorder WMGX674 and a microphone with flat frequency response. Male calling songs were analysed with CoolEdit96 and printed using Turbolab (Stemmer AG) program. The terminology of song description follows Ragge \& Reynolds (1998), Heller (1988), Orci et al. (2001) and Heller et al. (2004): calling song - song produced by an isolated male; syllable - sound produced during one opening and closing movement of the tegmina; syllable group (echeme) - a first-order assemblage of syllables; hemisyllable - the sound produced by one unidirectional movement (opening or closing) of the fore wings; syllable period - syllable plus interval until beginning of next syllable; impulse - a simple, undivided, transient train of sound waves (here; the highly damped sound impulse resulting from the impact of one tooth of the stridulatory file). In song descriptions the following abbreviations were used: ' $\mathrm{s}$ ' for seconds and ' $\mathrm{ms}$ ' for milliseconds.

\section{RESULTS}

The major group can be distinguished from other Isophya species by a combination of the following characters; the fastigium verticis not protruding and much narrower than scapus (roughly half as wide as scapus), the male tegmina as measured from the caudal margin of pronotum at least slightly longer than the pronotum, the ovipositor longer than $10 \mathrm{~mm}$, the hind femur with several spinules ventrally and the male cerci with two or more spines not ordered in a line. The male cercus is unique within the genus and is considered to be the synapomorphy that defines the species in this group.

\section{Key to the species}

Male

1 Cerci with 2-5 apical and 4-8 preapical denticles ...... 2

- Cerci with single apical and 1-3 preapical denticles ..... 3

2 Tegmina 1.4-1.5 (rarely 1.3) times as long as pronotum and narrow at apex (Figs 1,2); stridulatory file with less than 200 teeth $(128-156) \ldots \ldots \ldots \ldots \ldots \ldots \ldots$. . major

- Tegmina 1.0-1.1 (rarely 1.2) times as long as pronotum and wide at apex (Fig. 4); stridulatory file with more than 200 teeth $(200-240) \ldots \ldots \ldots \ldots \ldots \ldots$. . . . . . . . I. salmani

3 Stridulatory file with more than 200 teeth (200-240). .............................. I. salmani Stridulatory file with less than 200 teeth $(118-170) \ldots \ldots 4$

4 Tegmina 1.4-1.5 (rarely 1.3) times as long as pronotum (Fig. 3); stridulatory file with 118-140 teeth. . I. mersinensis - Tegmina 1-1.1 (rarely 1.2) times as long as pronotum (Fig. 5); stridulatory file with 149-170 teeth. . I. mavromoustakisi

Female

1 Ovipositor long, 2.4-3.0 times longer than pronotum . . . . 2 - Ovipositor short, 1.9-2.0 times longer than pronotum ...... ............................... I. salmani

2 Costal margin of left tegmen as long as or longer than anal margin, tegmen with apex convex (A in Figs 10, 11) . . . 3

- Costal margin of left tegmen shorter than anal margin, tegmen with apex straight or slightly projecting at anal corner (Fig. 13A). . . . . . . . . . I. mavromoustakisi

3 Ovipositor $12.2-14.9 \mathrm{~mm}$ and pronotum $4.4-5.5 \mathrm{~mm}$ (Table 1 ); tegmina shorter than or as long as half the length of pronotum. . . . . . . . . . . . . . . . . . I. mersinensis

- Ovipositor 10.3-11.9 mm, pronotum 3.5-4.4 mm (Table 1); tegmina longer than the half length of pronotum ... I. major

\section{Isophya major Brunner von Wattenwyl, 1878}

(Figs 1, 2, 6, 10, 14, 18, 22, 26, 30, 34, 38, 42, 48, 49; Tables 1, 2)

Isophya major Brunner von Wattenwyl, 1878: 70.

I. major Brunner von Wattenwyl, 1878: Werner, 1901: 289.

I. major Brunner von Wattenwyl, 1878: Uvarov, 1936: 510.

I. maior Brunner von Wattenwyl, 1878: Ramme, 1951: 345.

I. major Brunner von Wattenwyl, 1878: Bei-Bienko, 1954: 228.

I. major Brunner von Wattenwyl, 1878: Maran, 1958: 291.

I. major Brunner von Wattenwyl, 1878: Karabağ, 1958: 23 and 1964: 48 .

I. major Brunner von Wattenwyl, 1878: Karabağ et al., 1981: 4.

I. major Brunner von Wattenwyl, 1878: Güneş, 1984: 27 (misidentification, refers to I. mersinensis).

I. major Brunner von Wattenwyl, 1878: Heller, 1990: 149 (song record) (misidentification, refers to I. salmani).

I. major Brunner von Wattenwyl, 1878: Naskrecki \& Ünal, 1995: 398.

I. major Brunner von Wattenwyl, 1878: Ünal, 1997: 8 and 1999: 243; 2004: 3-4.

I. major Brunner von Wattenwyl, 1878: Naskrecki et al. (OSF2, 2005).

Isophya major muchei Harz, 1963: 195. syn. n. (as Isophya maior muchei). 

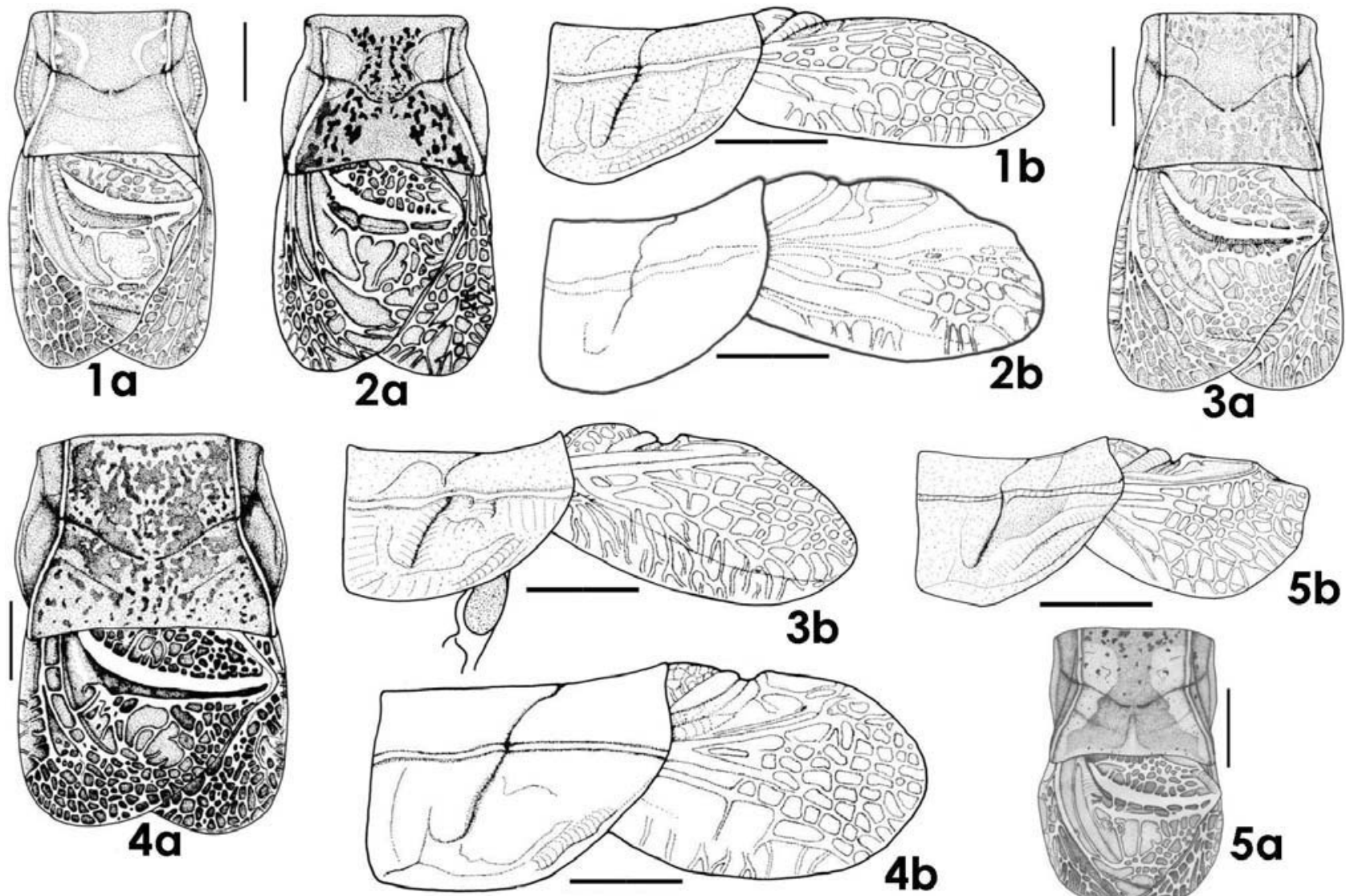

$4 b$

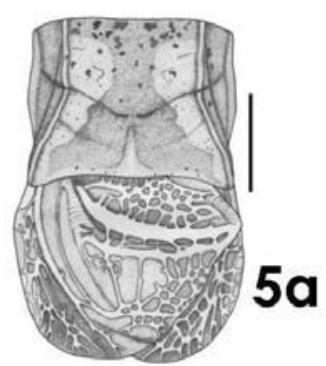

Figs 1-5. Male pronotum and tegmina. 1, 2 -I. major (1 - Konya, 2 - Niğde), 3 - I. mersinensis, 4 - I. salmani, 5 - I. mavromoustakisi. $\mathrm{a}-$ from above, $\mathrm{b}-$ in profile. Scale $=2 \mathrm{~mm}$.

Diagnosis. See key to species, Table 1-2 and discussion.

Redescription. Male. Fastigium verticis slender, as wide as or sligthly wider than half of scapus; strongly depressed dorsally, slightly tapered frontward and sulcate above.

Lateral keels on pronotum distinct and entire, sligthly convergent on the prozona and strongly divergent posteriorwards on the metazona; disc with a straight frontal margin and concave caudal margin, transversal sulcus located far beyond middle. Pronotum slightly concave dorsally (especially on the metazona) in profile paranota with frontal margin perpendicular, ventral margin short, caudal margin long and obtusely oblique; maximum height of paranota longer than half the length of pronotum (Figs 1, 2).

Tegmina roughly 1.5 times as long as pronotum, extends to middle of third abdominal tergum and narrowly rounded at caudal margin; tegminal disk longer than wide; $\mathrm{Cu} 2$ of left tegmen swollen, its length $3 / 4$ of caudal margin of pronotum, projecting at right margin; speculum obtusely triangular (Figs 1,2$)$. Stridulatory file $3.2-3.3 \mathrm{~mm}$ in length, with $128-156$ teeth, which gradually widen towards the middle and gradually narrow towards the apex (Fig. 22). Hind femur long, 3.9-4.0 times as long as pronotum and with numerous spines on margins.
Epiproct two times as wide as long; cerci short and strong, gradually narrow distalwards, distal 1/4-1/5 obtusely incurved and rounded apically; there are two rows of denticles distally; apical row includes 2-5 denticles the most internal of which being is the largest; preapical row includes 4-8 denticles (Fig. 6). Subgenital plate small, slightly tapering backwards, with a relatively deep triangular or sometimes rounded incision and acute lobes on caudal margin (Fig. 14).

Brownish or blackish green especially abdomen. Antennae yellowish, fastigium brown dorsally, vertex and occiput with small brownish patterns; disc of pronotum green or greenish-blue; tegmina yellowish with green margins, costal field whitish; legs greenish with brownish spots or patterns. Abdomen greenish with dark patterns, sometimes with two entire bilateral stripes dorsally.

Female. Head and pronotum roughly as in the male, but dorsum of pronotum almost straight or indistinctly concave (Fig. 10). Tegmina distinctly longer than half the length of pronotum, apex rounded (Fig. 10); there are 3-4 rows of stridulatory pegs on ventro-anterior half and twothree rows on ventro-posterior half (Fig. 26); hind femur long, 3.8 times as long as pronotum and with numerous ventral spines. Epiroct ellipsoid or semi-circular, cerci short. Ovipositor long, 2.5-3.0 times as long as pronotum; gradually curving and narrowing distalwards; with 8-11 spines on dorsal margin and 5-7 spines on 
TABLE 1. Measurements (in mm, mean $\pm \mathrm{SD}$ ) of the species of the $I$. major group.

\begin{tabular}{|c|c|c|c|c|c|c|}
\hline Species & Sex & Body & Pronotum & Tegmina & Hind femur & Ovipositor \\
\hline \multirow{2}{*}{ I. major } & $\begin{array}{c}\text { Male } \\
\mathrm{N}=14\end{array}$ & $\begin{array}{c}16-22.7 \\
(19.6 \pm 1.4)\end{array}$ & $\begin{array}{c}3.5-4.4 \\
(4.1 \pm 0.3)\end{array}$ & $\begin{array}{c}4.6-6.6 \\
(5.7 \pm 0.5)\end{array}$ & $\begin{array}{c}13.6-16.7 \\
(15.7 \pm 0.9)\end{array}$ & - \\
\hline & $\begin{array}{l}\text { Female } \\
\mathrm{N}=18\end{array}$ & $\begin{array}{c}18.1-26.5 \\
(21.5 \pm 1.9)\end{array}$ & $\begin{array}{c}3.95-5.5 \\
(4.5 \pm 0.3)\end{array}$ & $\begin{array}{c}2.8-3.5 \\
(3.1 \pm 0.2)\end{array}$ & $\begin{array}{c}15.1-18.2 \\
(16.8 \pm 0.9)\end{array}$ & $\begin{array}{c}10.3-11.9 \\
(11.7 \pm 0.5)\end{array}$ \\
\hline \multirow{2}{*}{ I. mersinensis } & $\begin{array}{c}\text { Male } \\
\mathrm{N}=10\end{array}$ & $\begin{array}{c}19.8-23.8 \\
(21.5 \pm 1.1)\end{array}$ & $\begin{array}{c}3.5-4.5 \\
(4.0 \pm 0.3)\end{array}$ & $\begin{array}{c}4.5-5.7 \\
(5.3 \pm 0.4)\end{array}$ & $\begin{array}{c}13.3-17.5 \\
(16.2 \pm 1.3)\end{array}$ & - \\
\hline & $\begin{array}{l}\text { Female } \\
\mathrm{N}=10\end{array}$ & $\begin{array}{c}21-25 \\
(23.2 \pm 1.2)\end{array}$ & $\begin{array}{c}4.4-5.5 \\
(4.9 \pm 0.2)\end{array}$ & $\begin{array}{c}2.1-3.2 \\
(2.6 \pm 0.3)\end{array}$ & $\begin{array}{c}16.8-19 \\
(18.3 \pm 0.8)\end{array}$ & $\begin{array}{c}12.2-14.9 \\
(13.6 \pm 0.8)\end{array}$ \\
\hline \multirow{2}{*}{ I. salmani } & $\begin{array}{c}\text { Male } \\
\mathrm{N}=10\end{array}$ & $\begin{array}{c}21.5-24.7 \\
(23.2 \pm 0.9)\end{array}$ & $\begin{array}{c}4.6-5.5 \\
(5.0 \pm 0.3)\end{array}$ & $\begin{array}{c}4.5-5.6 \\
(5 \pm 0.4)\end{array}$ & $\begin{array}{c}15.4-18.7 \\
(16.9 \pm 1.0)\end{array}$ & - \\
\hline & $\begin{array}{l}\text { Female } \\
\mathrm{N}=10\end{array}$ & $\begin{array}{c}21-26 \\
(23.7 \pm 1.6)\end{array}$ & $\begin{array}{c}5.4-6.5 \\
(5.9 \pm 0.4)\end{array}$ & $\begin{array}{c}1.9-2.5 \\
(2.2 \pm 0.2)\end{array}$ & $\begin{array}{c}13.6-16.7 \\
(15.7 \pm 0.9)\end{array}$ & $\begin{array}{c}10.7-12.5 \\
(11.2 \pm 0.5)\end{array}$ \\
\hline \multirow{2}{*}{$\begin{array}{l}\text { I. mavromous- } \\
\text { takisi }\end{array}$} & $\begin{array}{c}\text { Male } \\
\mathrm{N}=21\end{array}$ & $\begin{array}{c}16-19.3 \\
(18.0 \pm 0.7)\end{array}$ & $\begin{array}{c}3.2-4.1 \\
(3.7 \pm 0.2)\end{array}$ & $\begin{array}{c}3.6-4.3 \\
(3.9 \pm 0.2)\end{array}$ & $\begin{array}{c}13.3-14.7 \\
(13.9 \pm 0.4)\end{array}$ & - \\
\hline & $\begin{array}{l}\text { Female } \\
\mathrm{N}=14\end{array}$ & $\begin{array}{c}15-20 \\
(18.8 \pm 1.2)\end{array}$ & $\begin{array}{c}3.3-4.6 \\
(4.1 \pm 0.4)\end{array}$ & $\begin{array}{c}1.7-2.4 \\
(2.0 \pm 0.2)\end{array}$ & $\begin{array}{c}13.8-16.2 \\
(15.1 \pm 0.2)\end{array}$ & $\begin{array}{c}9.2-10.5 \\
(10 \pm 0.3)\end{array}$ \\
\hline
\end{tabular}

ventral margin (Fig. 30); gonangulum with convex caudal margin, lamella thin, small, unmodified, there is an indistinct pit between gonangulum and lamella. Subgenital plate triangular; angular or rounded at corners (Fig. 18). Coloration as in male.

Song. The songs of animals from three localities (road from Beyşehir to Akseki, Beyşehir and Konya-Hanönü)

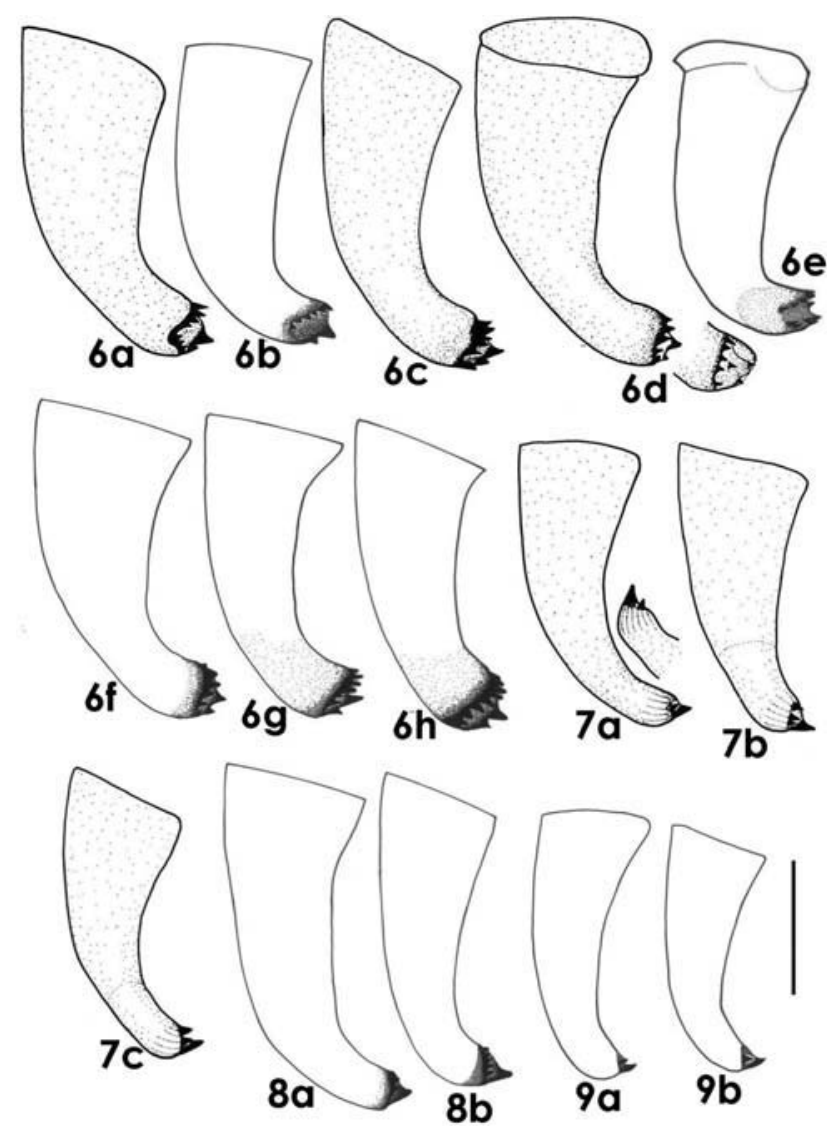

Figs 6-9. Male cerci. 6-I. major (a - Ankara, b - Antalya, c, $\mathrm{d}$, e and $\mathrm{f}-\mathrm{Niğde,} \mathrm{g,} \mathrm{h-Konya),} 7$ - I. mersinensis, 8 - I. salmani, $9-$ I. mavromoustakisi. Scale $=1 \mathrm{~mm}$. were recorded in the evening in the laboratory, at temperatures between $21-24^{\circ} \mathrm{C}$. The calling song consisted of a sequence of several groups of syllables (Fig. 34). The number of syllable groups in a sequence ranged from 4 to 12. Syllable number per group varied between $4-12$. The first syllable group of a sequence was composed of 6-12 syllables and had a duration of $350-750 \mathrm{~ms}$. It was thus longer than each of the subsequent groups, which consisted of 1-3 syllables of 60-210 ms duration (Figs 34, 42). The syllable groups were repeated at variable periods (syllable group + interval) of about $1.0-1.8 \mathrm{~s}$. The syllable duration ranged between 8 and $40 \mathrm{~ms}$ (mean $18 \mathrm{~ms}$ ), the average syllable period within a group between 50 and $187 \mathrm{~ms}$ (mean: $83 \mathrm{~ms}$ ). The number of impulses within one syllable varied between 2 and 14 and had an average value of 62 impulses per syllable $(\mathrm{n}=134$ syllables of 5 $\hat{0}$ ) (Figs 34, 38, 42). There were no significant differences between localities in respect to time pattern.

Material. Turkey: Holotype ô, İçel (Mersin), Gülek (Brunner von Wattenwyl 1878) (type not examined, but photos in OSF2 were examined); $1 \delta^{\hat{}}$, Turkey, Ankara, Aydos Dağ 1 , 15.v.1986 (collector unknown); 10 and 39 , Turkey, Antalya, Akseki, Akarcalar, 750 m, 23.v.1996; 1 , Turkey, Antalya, Gazipaşa, Sugözü Köyü, Maha yaylası, Akçal mevki, 05.viii. 1995; 1 ㅇ, Turkey, Antalya, İbradı, Sögüt yaylası, $1000 \mathrm{~m}$, 23.v.1996 (B. Çıplak) (AUZM); $3 \delta^{\widehat{o}}$ and 1 \% , Turkey, Antalya,

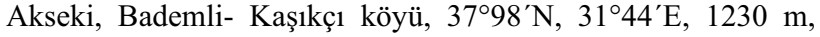
29.v.2001 (H. Sevgili) (HUZOM); $2 \widehat{o}$ and 29 , Turkey, Konya, vi.1945, (collector unknown) (ABDA); $2 \sigma^{\dagger}$ and $2 \%$, Turkey, Konya, 1945 (C. Kosswig) (1 0 and 19 in HUZOM, others in

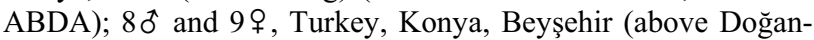
bey), $37^{\circ} 41^{\prime} \mathrm{N}, 31^{\circ} 55^{\prime} \mathrm{E}, 1400 \mathrm{~m}, 28 . v .2001 ; 5$; Turkey,

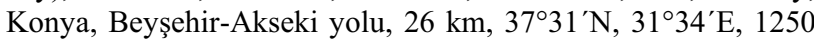
m, 29.v.2001; $20^{\dagger}$ and $4 \%$, Turkey, Konya, road to Beyşehir,

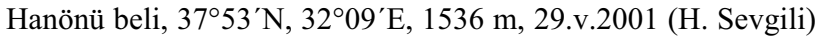
(HUZOM); 69 , Turkey, Konya, Sarayönü (Kayalıtepe), 11.vi. 1963, (N. Şişli) (ABDA); 2q, Turkey, Karaman, Ermenek, Balkıban köyü, 1963, 2 우 (collector unknown) (AZME); 10 and 1 ㅇ, Turkey, Kahramanmaraş, road between Sarız and Göksun, Binboğa Mts, 1400 m, 16.vii.1997 (B. Çıplak) (AUZM); 10, Turkey, Niğde, 1250 m, 19.vi.1952 (R. Çetik); 20 and 3 q, Tur- 
TABLE 2. Diagnostic characters of the species in the major group.

\begin{tabular}{|c|c|c|c|c|}
\hline Character & I. major & I. mersinensis & I. salmani & $\begin{array}{l}\text { I. mavro- } \\
\text { moustakisi }\end{array}$ \\
\hline Fastigium verticis extending to ridges of scapus & yes & yes & yes & no (shorter) \\
\hline Fastigium verticis slightly tapered distalwards & yes & yes & yes & no \\
\hline Fastigium verticis with a distinct sulcus & yes & yes & yes & $\begin{array}{l}\text { absent or } \\
\text { indistinct }\end{array}$ \\
\hline Index paranotum height / pronotum length in male & $>0.5$ & $=0.5$ & $>0.5$ & $>0.5$ \\
\hline Tegmina hyaline & no & no & no & yes \\
\hline Index length /width of tegminal disc in male & 1.5 & $1.3-1.4$ & $1-1.1$ & $1-1.1$ \\
\hline Index lengths of tegmina / pronotum in male & (1.3)1.4-1.5 & (1.3)1.4-1.5 & $1.1-1.2$ & $1.1-1.2$ \\
\hline Index lengths of tegmina / pronotum in female & $>0.5$ & $0.4-0.5$ & $0.4-0.5$ & $0.4-0.5$ \\
\hline Male tegmina caudally & narrow & wide & wide & wide \\
\hline $\begin{array}{l}\text { Costal margin of tegmen obviously shorter than anal } \\
\text { margin in female }\end{array}$ & no & no & yes & yes \\
\hline Hind margin of tegmina in female & rounded & rounded & $\begin{array}{l}\text { roughly } \\
\text { quadrangular }\end{array}$ & $\begin{array}{c}\text { roughly } \\
\text { quadrangular }\end{array}$ \\
\hline Index lengths of hind femur / pronotum & $3.8-4$ & $3.8-4$ & $3.3-3.4$ & $3.8-3.9$ \\
\hline No. of apical teeth in the apical row on the male cerci & $2-5$ & 1 & $1-2$ & 1 \\
\hline No. of apical teeth in the pre-apical row on the male cerci & $4-8$ & $1-3$ & $3-6$ & $1-2$ \\
\hline Index length of ovipositor / pronotum & $2.5-3$ & $2.6-3$ & $1.9-2$ & 2.4 \\
\hline No. of stridulatory teeth & $128-144$ & $118-140$ & $200-235$ & $149-170$ \\
\hline Basic unit of calling song & $\begin{array}{l}\text { sequence of } \\
\text { syllable groups }\end{array}$ & $\begin{array}{l}\text { sequence of syllable } \\
\text { groups }\end{array}$ & $\begin{array}{l}\text { syllable } \\
\text { group }\end{array}$ & $\begin{array}{l}\text { syllable } \\
\text { group }\end{array}$ \\
\hline No. of syllable types & 1 & 2 & 2 & 2 \\
\hline $\begin{array}{l}\text { Duration of syllable }(\mathrm{m}=\text { mean; A, B different syllable } \\
\text { types) }\end{array}$ & $\begin{array}{c}8-40 \mathrm{~ms} \\
(\mathrm{~m}=18 \mathrm{~ms})\end{array}$ & $\begin{array}{l}\text { A: } 8-33 \mathrm{~ms}(\mathrm{~m} 17 \mathrm{~ms}) \\
\text { B: } 25-99 \mathrm{~ms}(\mathrm{~m} 60 \mathrm{~ms})\end{array}$ & $\begin{array}{l}\text { A: } 0.9-2.1 \mathrm{~s} \mathrm{~B}: \\
0.4-1.1 \mathrm{~s}\end{array}$ & $\begin{array}{l}\text { A: } 0.2-0.3 \mathrm{~s} \\
\text { B: } 0.2-0.3 \mathrm{~s}\end{array}$ \\
\hline $\begin{array}{l}\text { Syllable-/syllable group period } \\
\text { E - Erdemli } \\
\text { G - Güzelyayla }\end{array}$ & $\begin{array}{c}50-187 \mathrm{~ms} \\
(\mathrm{~m}=83 \mathrm{~ms}) \\
1-1.8 \mathrm{~s}\end{array}$ & $\begin{array}{c}\text { E: } 44-120 \mathrm{~ms}(\mathrm{~m} 67.5 \mathrm{~ms}) \\
\mathrm{G}: 54-122 \mathrm{~ms}(\mathrm{~m}: 78.2 \mathrm{~ms}) \\
/ 0.9-2.7 \mathrm{~s}\end{array}$ & $2.6-5.3 \mathrm{~s}$ & $1.7-2.2 \mathrm{~s}$ \\
\hline Temperature during sound recording & $21-24^{\circ} \mathrm{C}$ & $24-27^{\circ} \mathrm{C}$ & $22-25^{\circ} \mathrm{C}$ & $22^{\circ} \mathrm{C}$ \\
\hline
\end{tabular}

key, Niğde, Ulukışla, Bolkar Mts, Darboğaz, Karagöl yaylası, 1900-2300 m, 07.viii.1996 (B. Çıplak) (1 ô and 1 o in AUZM, others in HUZOM;); 1 ô, Turkey, Niğde, Ulukışla (date and collector unknown) (AZME).

Previous records. Turkey. Holotype $\widehat{\delta}$, İçel (Mersin), Gülek (Brunner von Wattenwyl, 1878); 10, Adana, Bürücek yaylas1, viii.1953 (H. Kumerloeve) (Mařan, 1958); 20ิ, 1우 Turkey, Adana, Pozantı 19.v.1981 and 10 , the same locality, 26.v.1981 (H.V. Güneș); 4 ô and 2 क , Turkey, Mersin, Gülek, 20.vi.1982 (H.V. Güneş) (Güneş, 1984); $1 \delta^{\text {to }}$ and 1 9 , Turkey, Efrenk on Cilician Taurus, 1904, (Holtz = M. Gol'ts); unknown number of specimens, Anatolia (Turkey), Nigde, Ulukisla (W. Ramme); unknown number of specimens, between Konya and Kayseri (Penther); unknown number of specimens, Karaman (Schaefer) (Ramme, 1951; Bei-Bienko, 1954); $7 \hat{\delta}$ and 3ㅇ. Turkey, Mersin, Sertavul pass, 4800 ft, 21.vi.1960 (Karabağ, 1964); 3 ते $^{\circ}$ and $4 \%$, Turkey, Mersin, Bolkar Mts (Gülek), 1961, (W.H. Muche) (Harz, 1963; as I. major muchei); $3 \hat{0}$ and 19 , Konya, vi.1945 (C. Kosswig) (Karabağ, 1958); 40 and 1 + , Turkey, Karaman, Ermenek, Kazancı köyü, 14.vi.1973 (Karabağ et al., 1981); 1 ㅇ, Karaman, Karadağ, 1080 m, 17.vi.2003; 50, 3 , the same locality, $1150 \mathrm{~m} ; 1 \delta^{\hat{\sigma}}$, the same locality, $2278 \mathrm{~m} ; 1 \delta^{\hat{0}}$,

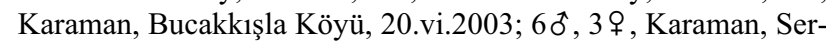
tavul Geçidi, 1650 m, 18.vi.2003 (M. Ünal) (Ünal, 2004); 10 ô and 1\%, Turkey, Konya, Belenbaş1, 1500 m, 22.vi.1991 (M. Ünal) (Ünal, 1999); 10, Konya, Güneysınır, $1130 \mathrm{~m}$, 19.vi.2002 (M. Ünal) (Ünal, 2004); $3 \delta^{\hat{0}}$ and 2 $\$$, Turkey, Nevșe- hir, Avanos, Ziyaret dağı $1565 \mathrm{~m}, 13 . v i .1993 ; 20$ and 1 \%, Turkey, Nevşehir, Avanos, Topuzdağı, 1535 m (M. Ünal) (Ünal, 1997); 1 $\widehat{0}, 1$ ㅇ, Nevşehir, Acıgöl, Yalman Köyü, 1270 m, 21.vi.2002 (M. Ünal) (Ünal, 2004)

The following previous records of $I$. major refer to the $I$. mersinensis or I. salmani described in this text. $1 \%$, Turkey, Hatay, Kırıkhan, 13.v.1982 (H.V. Güneş); $60^{\star}$ and 8 \% , Turkey, Mersin, Kuzucubelen, 21.v.1981; 1 , Turkey, Mersin, Tarsus, 26.v.1981 (H.V. Güneş) (Güneş, 1984); $50 \hat{~ a n d ~ 4}+$, Turkey, Mersin, Gözne, 02.-03.vi.1960 (K.M. Guichard and D.H. Har-

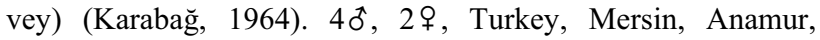
18.iv.1987 (Heller, 1990).

Remarks. Previous records of this species from low elevations in the Adana and Mersin provinces (possibly also those from Hatay) may refer to I. mersinensis, which is described here or to another unknown species. The range of $I$. major is based on the material examined.

This species has been recorded from peripheral parts of Central Anatolia, mainly from the northern side of the Southern Taurus (from Antalya in the west to NiğdeKahramanmaraş in the east) and western slopes of the Anatolian Diagonal Belt (from Mersin in the south to Ankara in the north) (Fig. 39). Within the range of the species, specimens were collected from high altitudes (above $1000 \mathrm{~m}$ on Astragallus spp.). Vegetation at the 

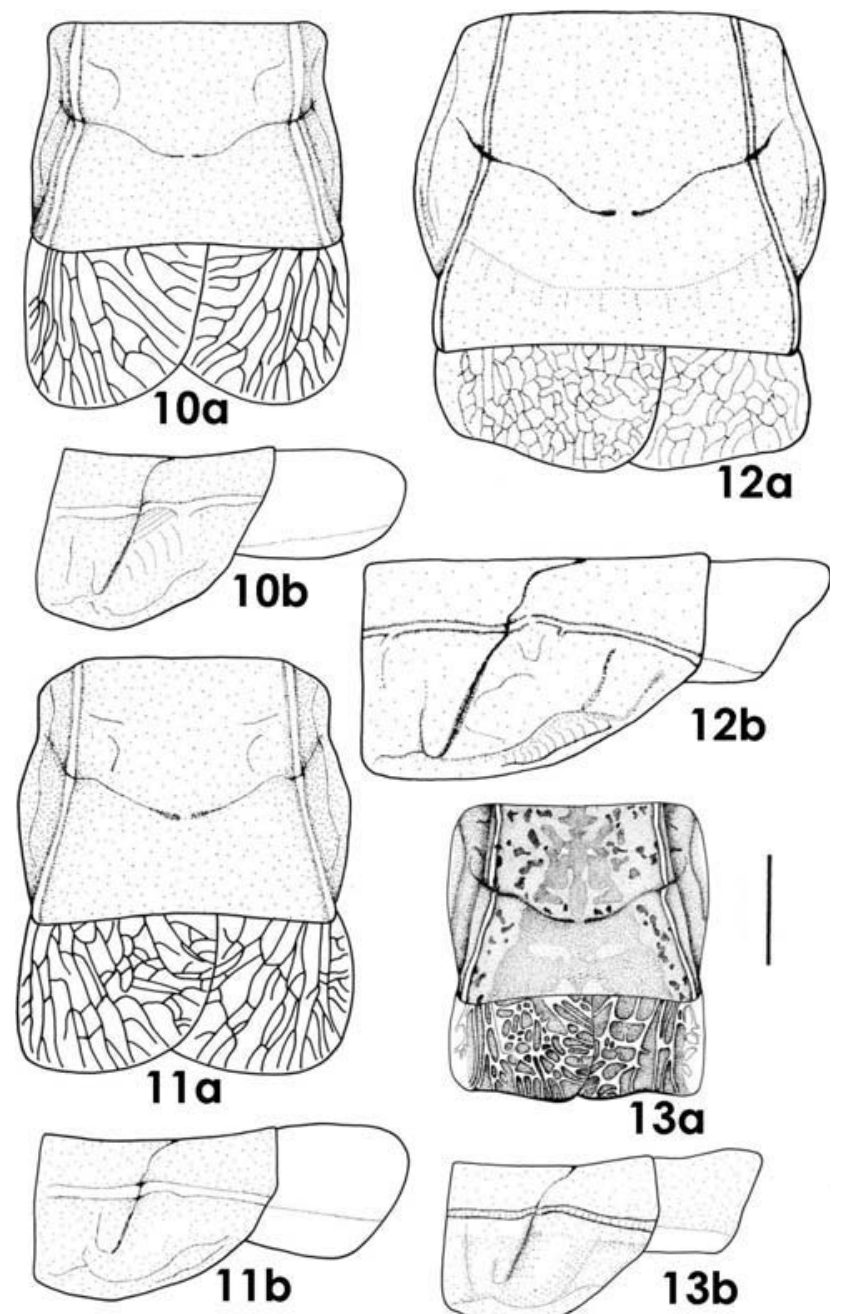

Figs 10-13. Female pronotum and tegmina. 10 - I. major, 11 - I. mersinensis, 12 - I. salmani, 13 - I. mavromoustakisi. a from above, $\mathrm{b}-$ from profile. Scale $=2 \mathrm{~mm}$.

collection sites was typical alpine or subalpine of the Irano-Anatolian or Mediterranean phytogeographical provinces. The field observations indicate the distribution of the species may be continuous along the mountain belts but disjunct in the lowlands. Probably because of this distribution there are local populations and considerable variation between local forms. For example, ovipositor length decreases toward the east. Denticulation on the male cerci, body length, ornamentation of teeth on the stridulatory organ of female, structure of male and female subgenital plates also varies. These variations are not consistently correlated with geographic fragmentation in the range and can not used for defining regional populations as separate species. Therefore all records from Central Anatolia (north of Southern Taurus and west of Diagonal Belt) are considered to belong to a single species.

Harz (1963) described and differentiated Isophya major muchei from the nominate subspecies only in coloration. However, coloration varies not only between localities (Ünal, 2004) but also between young and old individuals (observations by some of the authors). The type specimens of this subspecies were collected from the same
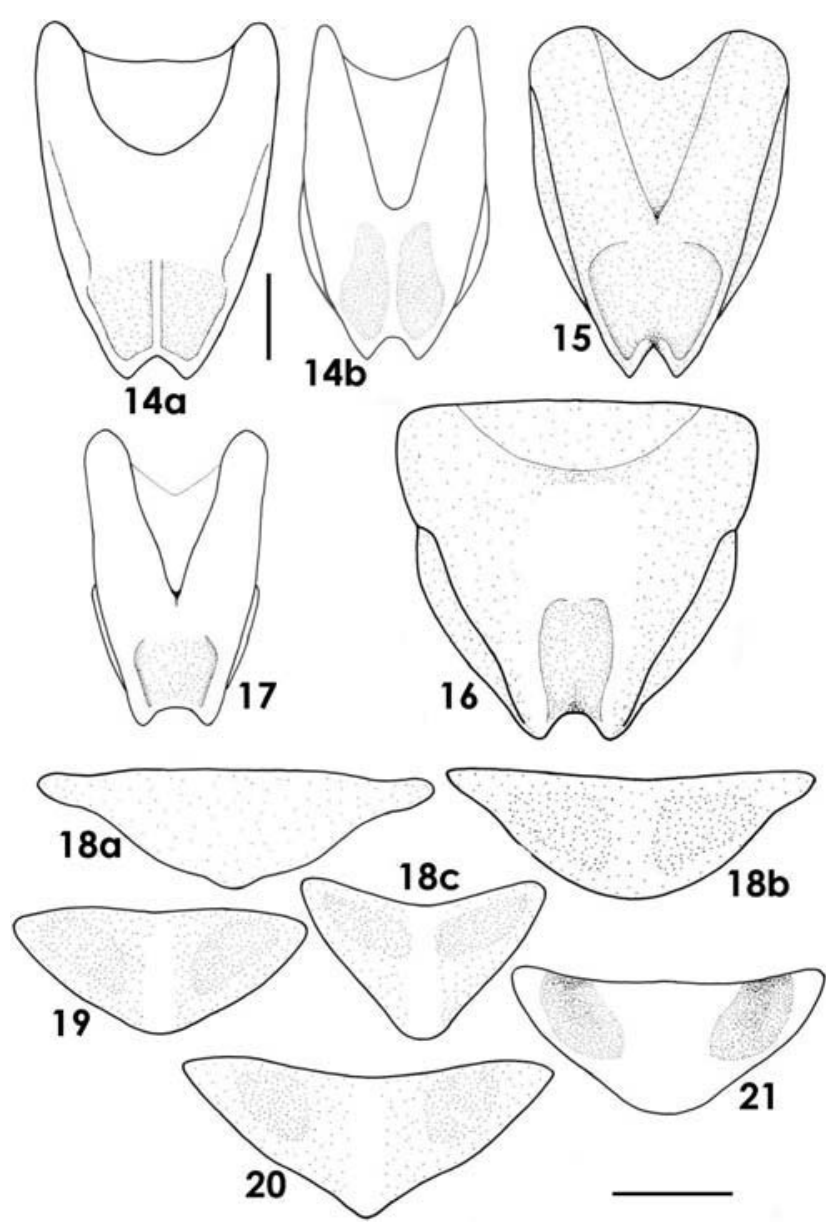

Figs 14-21. 14-17: Male subgenital plate. 14 - I. major (a, b - Niğde), 15 - I. mersinensis, 16 - I. salmani, 17 - I. mavromoustakisi. 18-21: Female subgenital plate (scale = $1 \mathrm{~mm}) .18-$ I. major ( $\mathrm{a}, \mathrm{b}$ - Antalya road from Akseki to Beyşehir, c Konya-Doğanbey), $19-I$. mersinensis, $20-I$. salmani, $21-I$. mavromoustakisi. Scale $=1 \mathrm{~mm}$.

locality as that of the nominate subspecies. Thus, Isophya major muchei Harz, 1963 is synonymized with the nominate subspecies.

\section{Isophya mersinensis Sevgili \& Çıplak sp. $\mathbf{n}$.}

(Figs 3, 7, 11, 15, 19, 23, 27, 31, 35, 39, 43, 46, 48, 49; Tables $1,2)$

Diagnosis. See key to species, Table 1-2 and discussion.

Description (holotype, male). Fastigium vertices half the width of scapus, narrowing apically, strongly depressed and sulcate dorsally.

Lateral keels on pronotum distinct and entire, parallel on prozona and regularly divergent backwards on metazona; typical sulcus located in $2 / 3$ from anterior, frontal and caudal margins of the disc straight. Pronotum with dorsal margin in profile indistinctly concave; paranota with frontal margin perpendicular, ventral margin long, caudal margin short and roundly oblique; maximum height of paranota roughly equal to half the length of pronotum (Fig. 3). 

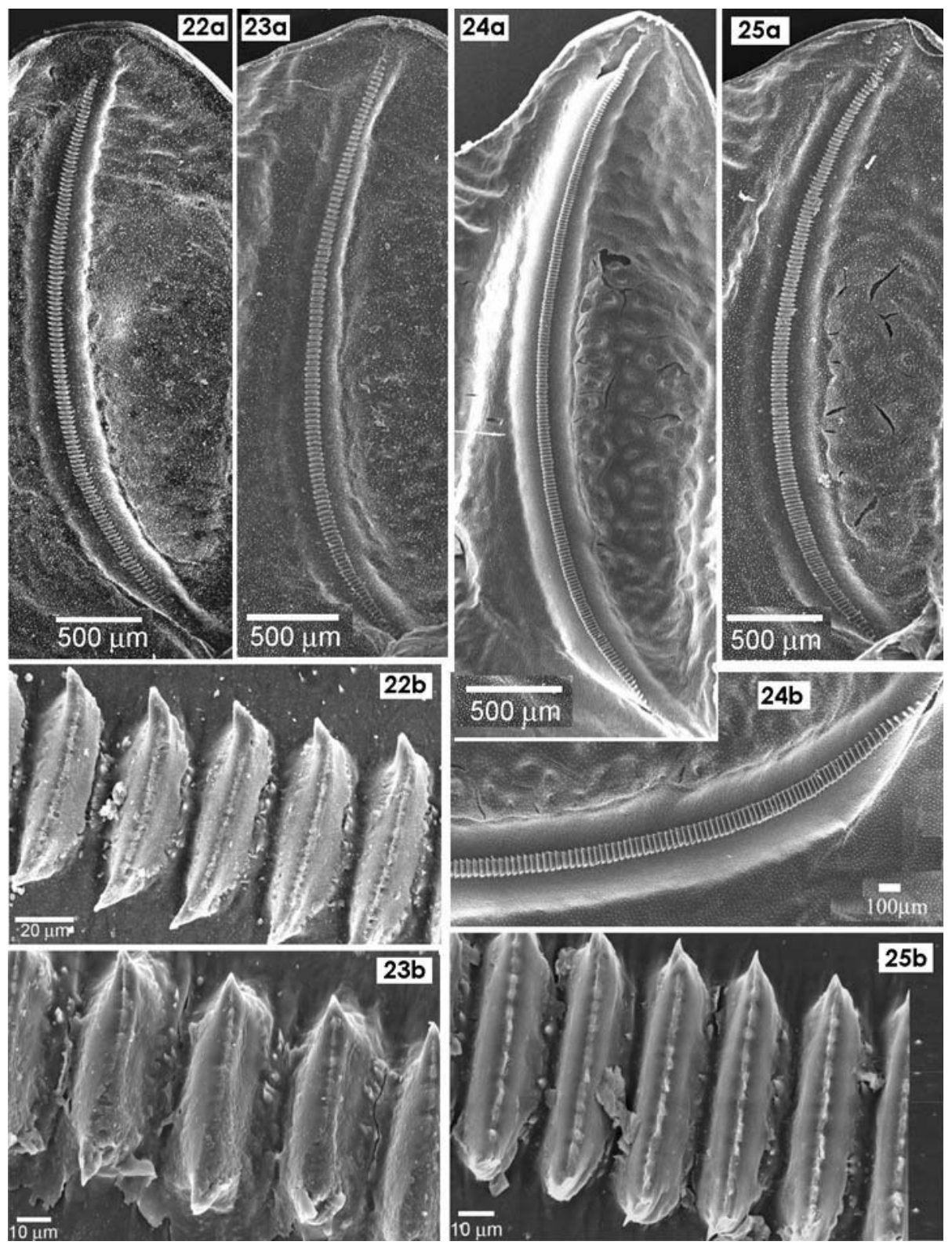

Figs 22-25. Male stridulatory teeth. 22 -I. major, 23 - I. mersinensis, 24 - I. salmani, 25 - I. mavromoustakisi. a - total file, b medial teeth at higher magnification.

Tegmina 1.3-1.4 times as long as pronotum, extending slightly beyond second abdominal tergum, apex rounded; tegminal disc longer than wide; $\mathrm{Cu} 2$ of left tegmen swollen, its length slightly less than caudal margin of pronotum, roundly projecting from right margin of tegmen; speculum small and triangular (Fig. 3). Stridulatory file $3.2 \mathrm{~mm}$ in length, with $118-140$ teeth, each gradually widening towards middle and gradually narrowing towards apex (Fig. 23). Hind femur approximately four times longer than pronotum, with numerous spines on margins.

Epiproct twice as wide as long; cerci short, wide at base, gradually narrowing distalwards, distal 1/4-1/5 obtusely incurved, rounded or slightly swollen apically; there are two rows of $2-5$ denticles, ventral row with a single large denticle (the apical denticle), dorsal row (pre- apical denticles) with 1-4 smaller denticles (Fig. 7). Subgenital plate slightly tapering backwards with almost parallel margins, with a deep triangular incision and tapering lobes on hind margin (Fig. 15).

Coloration. Green or brownish green. Antennae yellow, fastigium brown dorsally, vertex and occiput with small brown patterns; disc of pronotum green or greenish-blue; tegmina yellow with green margins, costal field white; legs green with brown patterns. Abdomen green with brown dots, sometimes with an entire yellow dorsal stripe.

Female. Fastigium verticis slightly wider than half of scapus, distinctly depressed and dorsally sulcate. Pronotum in general structure as in male, dorsal margin almost straight in profile; height of paranota hardly equal to half the length of pronotum (Fig. 11). Tegmina slightly 

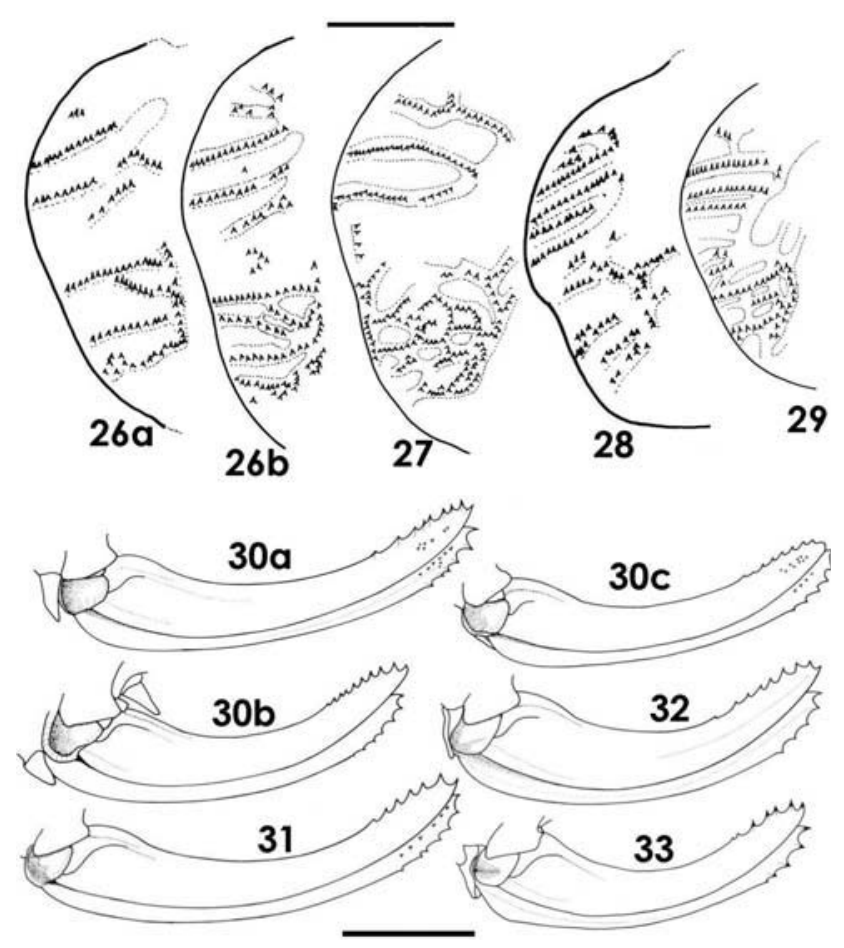

Figs 26-33. 26-29: Female stridulatory teeth. $26-I$. major (a, b - Antalya), 27 - I. mersinensis, 28 - I. salmani, $29-I$. mavromoustakisi. 30-33: Ovipositor (scale $=1 \mathrm{~mm}$ ). $30-I$. major (a - Antalya, b - Konya, c - Niğde), $31-I$. mersinensis, $32-$ I. salmani, $33-$ I. mavromoustakisi. Scale $=1 \mathrm{~mm}$.

longer than half the length of pronotum, roughly quadrangular or with a slightly convex hind margin (Fig. 11); there are three rows of stridulatory pegs on ventroanterior half and a network of ventral spinules on ventro posterior half (Fig. 27).

Epiproct ellipsoid; cerci short, reaching to apical half of epiproct, apex conical. Ovipositor long, 2.6-3.0 times as long as pronotum; gradually curving and narrowing dis- talwards; with 8-10 spinules on dorsal margin and 5-7 spinules on ventral margin (Fig. 31); gonangulum rounded; lamella thin, joint to gonangulum forming a distinct pit. Subgenital plate small and triangular, obtusely rounded or weakly projected on caudal margin (Fig. 19).

Song. Male calling songs were recorded from two different sites (Erdemli-Mersin and Güzelyayla-Mersin) in the evening/nigth at $24-27^{\circ} \mathrm{C}$ (Fig. 35). They consisted of an irregularly repeated sequence of syllable groups. The number of syllable groups per sequence ranged between 2 and 27 , but was usually $3-10$. The duration of one sequence varied between 3.5-40.0 s (mean: $13 \mathrm{~s}$ ). Sequences of 1 minute or more (1-3 min, with more than 80 syllable groups) occured occasionally. Each sequence usually ended with few series of short syllable groups (usually 1-3 syllable) (Figs 35, 39, 43). The syllable group periods lasted between 1 and $2.8 \mathrm{~s}$ (mean: $1.7 \mathrm{~s}$ ) and that of a group between 85 and 377 ms (mean: 217 $\mathrm{ms})$. However, there was a difference between the Erdemli and Güzelyayla populations in the mean syllable period, which was $67.5 \mathrm{~ms}$ (range $44-120 \mathrm{~ms}$, at $27^{\circ} \mathrm{C}$ ) in the former and $78.2 \mathrm{~ms}$ (range $54-122 \mathrm{~ms}$ at $24^{\circ} \mathrm{C}$ ) in the later. The impulse number per syllable was about 3-16 (mean 6) but the last syllable within each group (echeme) was unusually long and consisted of 11-27 impulses (Figs 39, 46). However, there was significant variation between the two sites (Erdemli and Güzelyayla) in the duration and number of impulses in the last syllable (except the syllable groups in the late of the song). The impulse number in the last syllable in the Erdemli population was higher than that of Güzelyayla population. The average impulse number per syllable was 21.5 in the Erdemli (6ð) and 15.5 in the Güzelyayla (10 $\widehat{\jmath})$ population. Also, the duration of the last syllable was $52-99 \mathrm{~ms}$ (mean $79.3 \mathrm{~ms}$ ) in the Erdemli and 25-60 ms (mean 39.4 $\mathrm{ms})$ in the Güzelyayla population.
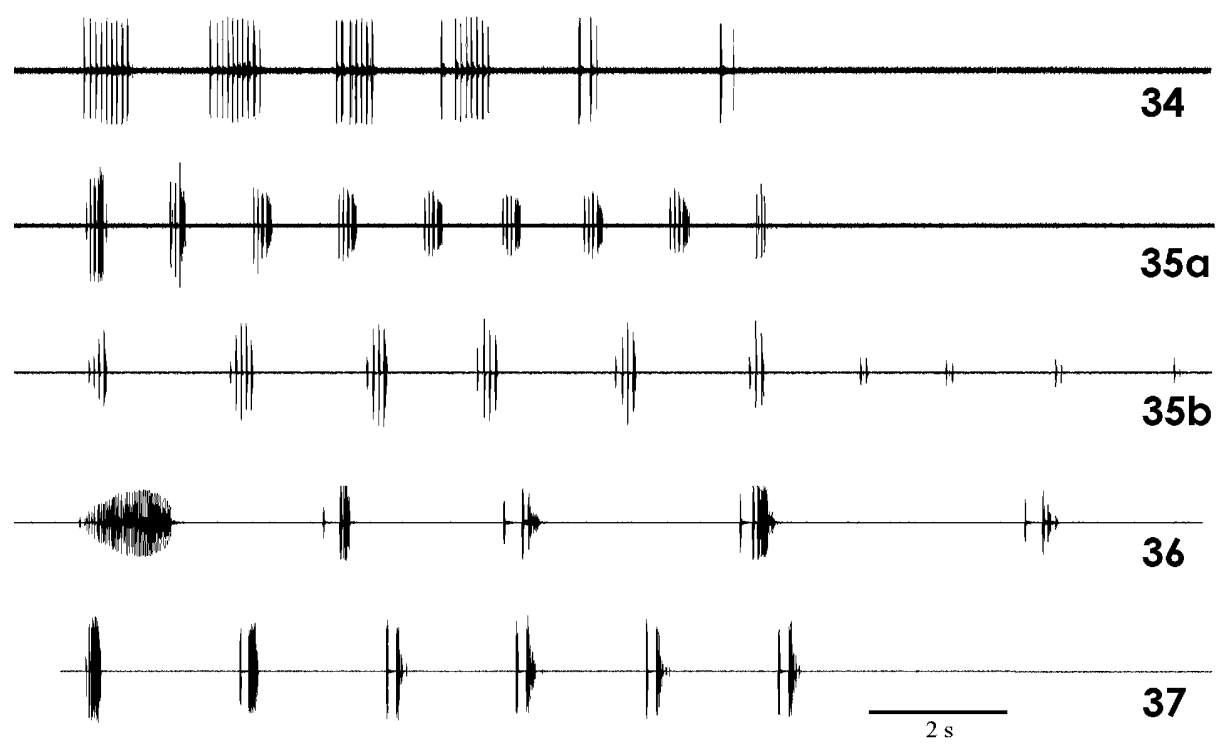

Figs 34-37. Structure of male calling songs of four Isophya species. $34-$ I. major (Beyşehir, $\left.24^{\circ} \mathrm{C}\right)$; $35-I$. mersinensis (a Mersin-Erdemli, $27^{\circ} \mathrm{C} ; \mathrm{b}$ - Mersin-Güzelyayla $\left.-24^{\circ} \mathrm{C}\right) ; 36-$ I. salmani (Mersin-Anamur, $\left.25^{\circ} \mathrm{C}\right) ; 37$ - I. mavromoustakisi $\left(22^{\circ} \mathrm{C}\right)$. 

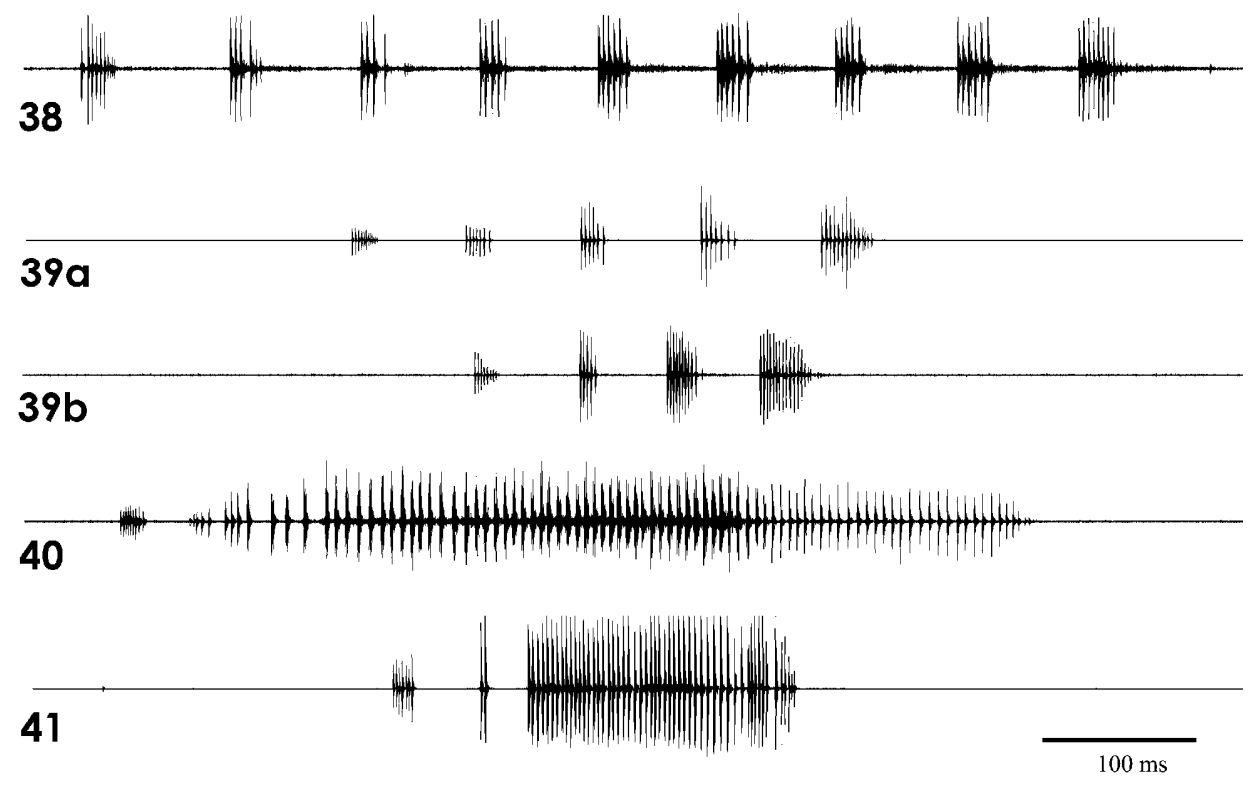

Figs 38-41. Oscillograms of first syllable group or first syllable of male songs. $38-I$. major $\left(24^{\circ} \mathrm{C}\right) ; 39-I$. mersinensis (a Mersin-Erdemli, $27^{\circ} \mathrm{C}$; b - Mersin-Güzelyayla, $\left.24^{\circ} \mathrm{C}\right) ; 40$ - I. salmani $\left(22^{\circ} \mathrm{C}\right) ; 41-$ I. mavromoustakisi $\left(22^{\circ} \mathrm{C}\right)$.

Material. Holotype $\delta^{\star}$, Turkey, Mersin, Erdemli, road to Güzeloluk yaylası, $36^{\circ} 47^{\prime} \mathrm{N}, \quad 34^{\circ} 4^{\prime} \mathrm{E} ; 36^{\circ} 32^{\prime} \mathrm{N}, \quad 33^{\circ} 28^{\prime} \mathrm{E}$, 750-1500 m, 10.vi.2002 (H. Sevgili) (HUBM); paratypes 13 đ, $13+$, same data as holotype; paratypes $10^{\top}$ and $1 \%$, Turkey, Mersin, Erdemli-Kösereli köyü, $36^{\circ} 32^{\prime} \mathrm{N}, 33^{\circ} 28^{\prime} \mathrm{E}, 900 \mathrm{~m}$, 16.vi.1995, $1 \delta^{\star}, 1$ 우 (B. Çılak) (HUBM); paratypes 30 0 , 17 우, Turkey, Mersin, Güzelyayla, Sancar mevkii, $3^{\circ} 01^{\prime} 084^{\prime \prime} \mathrm{N}$, $34^{\circ} 29^{\prime} 661^{\prime \prime} \mathrm{E}, 870 \mathrm{~m}, 17 .-25 . v .2003$ (H. Sevgili); paratypes 40’, 1 ㅇ, Turkey, Mersin, Güzelyayla, Eskigüzle mevkii, $37^{\circ} 02^{\prime} 380^{\prime \prime}$ N, 34³0'506"E, 920 m (H. Sevgili); paratypes $23 \sigma^{\circ}, 10$ \%, Turkey, Mersin, Soğucak yaylası, road to Gözne, 36 $57^{\prime} 958^{\prime \prime} \mathrm{N}$, 3434'031"E, 725 m, 19.v.2003 (H. Sevgili) (HUBM).

The following previous records for I. major are attributed to this species: $5 \hat{0}$ and $4 \%$, Turkey, Mersin, Gözne, 02.-03.vi. 1960 (K.M. Guichard and D.H. Harvey) (Karabağ 1964); 1 , Turkey, Hatay, Kırıkhan, 13.v.1982 (H.V. Güneş); $6{ }^{\dagger}$ and 8 \% Turkey, Mersin, Kuzucubelen, 21.v.1981; 1 우, Turkey, Mersin, Tarsus, 26.v.1981 (H.V. Güneş) (Güneş, 1984).
Etymology. "Mersin" province (Turkey) is the type locality of this new species.

\section{Isophya salmani Sevgili \& Heller sp. $\mathbf{n}$.}

(Figs 4, 8, 12, 16, 20, 24, 28, 32, 36, 40, 44, 48, 49; Tables 1, 2)

Diagnosis. See key to species, Table 1-2 and discussion part of the text.

Description (holotype, male). Fastigium verticis as wide as half of scapus, narrowing distalwards, depressed and sulcate dorsally.

Lateral keels of pronotum distinct and entire, almost parallel in prozona and strongly diverging backwards on metazona up to near caudal margin and then almost parallel; frontal margin of the disk straight, caudal margin weakly concave; disk of pronotum slightly swollen on metazona. Pronotum with dorsal margin in profile straight
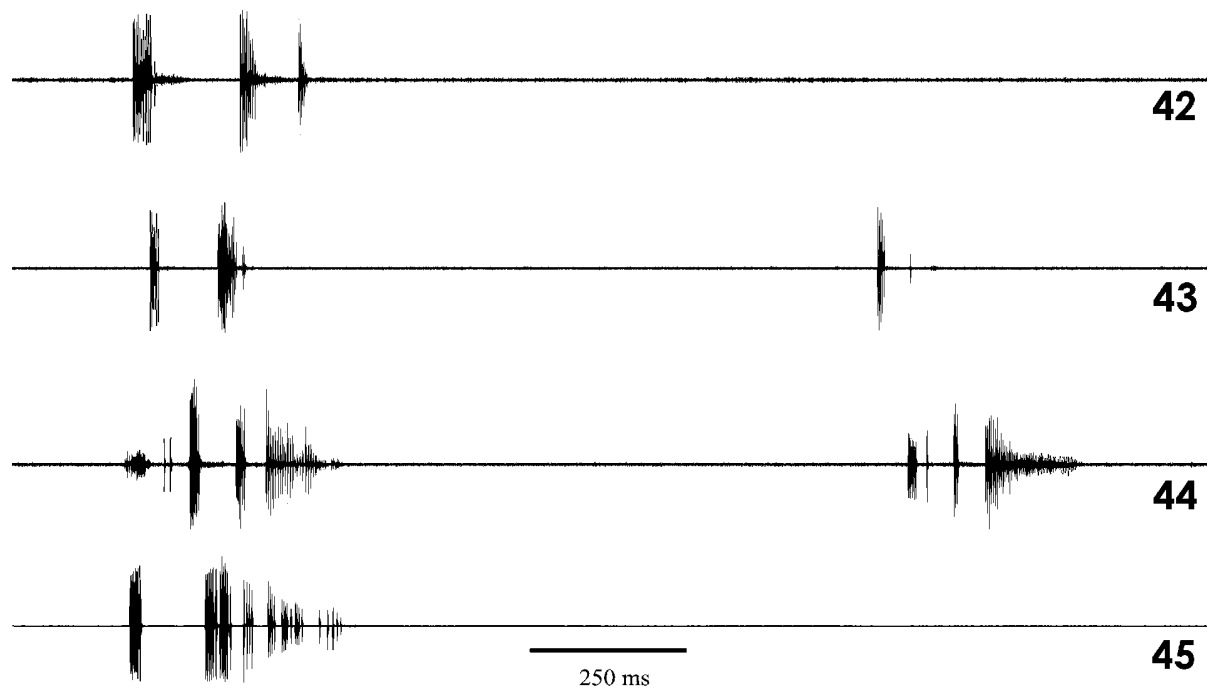

Figs $42-45$. Oscillograms of the last syllable group of male songs. $42-I$. major $\left(24^{\circ} \mathrm{C}\right), 43-I$. mersinensis $\left(27^{\circ} \mathrm{C}\right), 44-I$. salmani $\left(22^{\circ} \mathrm{C}\right), 45-$ I. mavromoustakisi $\left(22^{\circ} \mathrm{C}\right)$. 

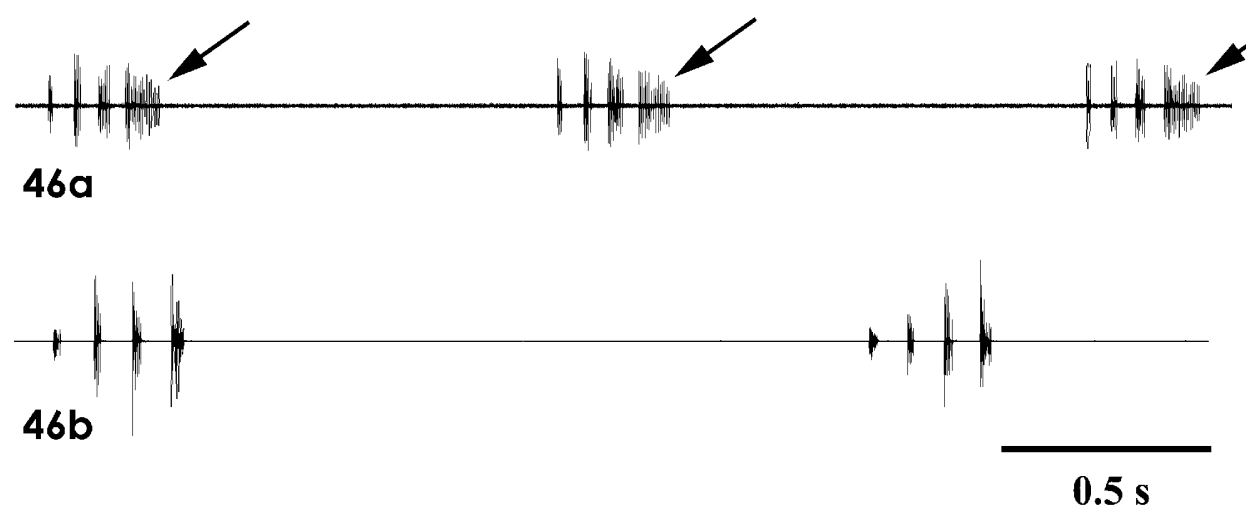

Fig. 46. Oscillogram of three syllable groups of I. mersinensis $\left(27^{\circ} \mathrm{C}\right)$. The last syllable is clearly longer than the preceeding (marked by the arrows) $\left(\mathrm{a}-\right.$ Mersin-Erdemli, $27^{\circ} \mathrm{C}$; b - Mersin-Güzelyayla, $\left.24^{\circ} \mathrm{C}\right)$.

or indistinctly concave; paranota with frontal margin slightly oblique, anterior $2 / 4$ or 3/4 of ventral margin long and straight, caudal margin short and oblique, maximum height of paranota more than half the length of pronotum (Fig. 4).

Tegmina as long as or slightly shorter than pronotum, hardly extending to hind margin of second abdominal tergum, apex rounded; tegminal disk roughly as long as wide; $\mathrm{Cu} 2$ of left tegmen distinctly swollen, its length roughly $3 / 4$ of caudal margin of pronotum, acutely projecting at right margin of tegmen; speculum obtusely/triangular (Fig. 4). Stridulatory file $4.6 \mathrm{~mm}$ long, with 200-240 teeth each gradually widening towards the middle and gradually narrowing towards the apex (Fig. 24). Hind femora short, 3.3-3.4 times as long as pronotum and with numerous spines on ventral margins.

Epiproct twice as wide as long; cerci short, wide or proximal 3/4 narrowing distalwards; distal 1/5-1/6 incurved into an almost right angle, rounded and with a robust denticle (sometimes an additional small denticle) at apex and a row of 3-6 pre-apical denticles on dorsal side (Fig. 8). Subgenital plate large at base, strongly tapering posteriorwards, with a deep rounded incision and robust lobes on caudal margin (Fig. 16).

Coloration. Brownish or blackish green, especially the abdomen. Antennae yellow, fastigium brown dorsally, vertex and occiput with small brown patterns; disc of pronotum green or greenish-blue; tegmina yellow with green margins, costal field white; legs green with brown patterns. Abdomen green with dark patterns, sometimes with two entire bilateral stripes dorsally.

Female. Fastigium verticis as in male. Pronotum as in male, but lateral keels more divergent on metazona, disc sligthly swollen, dorsal margin almost straight in profile (Fig. 12). Tegmina equal to or shorter than half the length of pronotum (Fig. 12); roughly quadrangular; with 4-6 rows of dense stridulatory pegs on ventro-anterior half and a few irregular rows of stridulatory pegs on ventroposterior half (Fig. 28). Hind femur roughly 3.3 times as long as pronotum, with numerous ventral spinules.
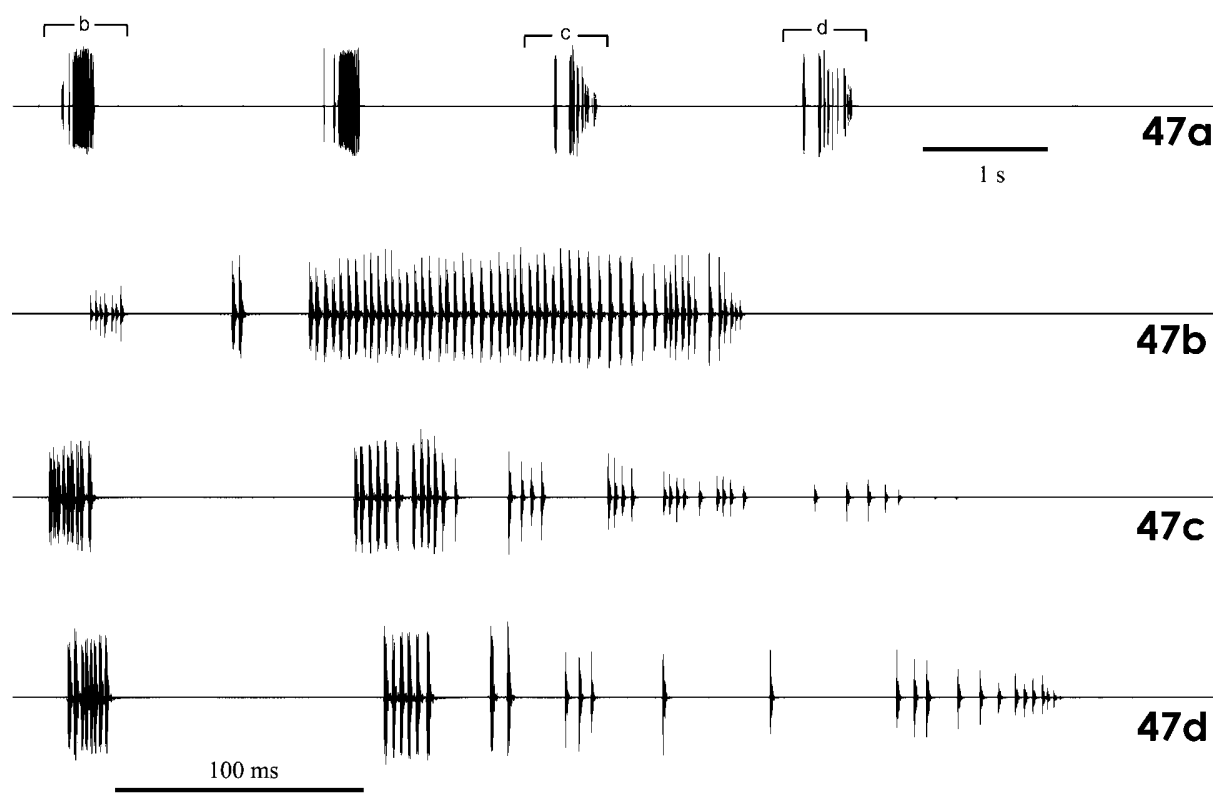

Fig. 47. The calling song of I. mavromoustakisi $\left(22^{\circ} \mathrm{C}\right)$. a - oscillogram of the calling song, $\mathrm{b}-\mathrm{d}-$ oscillograms showing single syllables of the male song. 


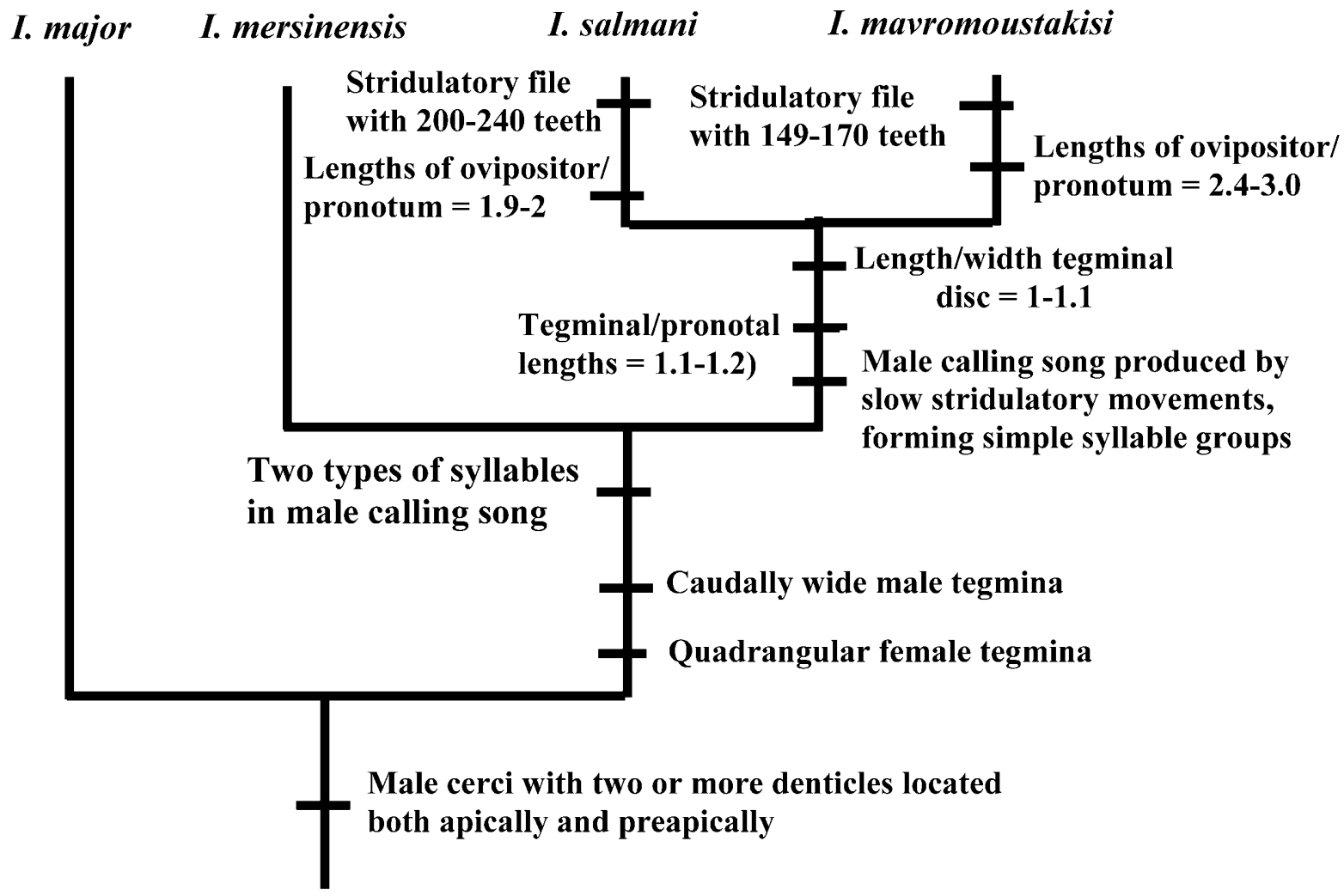

Fig. 48. Assumed phylogenetic relationships of the species of the I. major group.

Epiproct semi-circular or ellipsoid; cerci short, conic and slightly incurved, extending beyond hind margin of epiproct. Ovipositor 1.9-2.0 times as long as pronotum, gradually upcurving and narrowing distalwards, with 7-11 spines on dorsal margin and 5-8 on ventral margin (Fig. 32); gonangulum small and rounded, lamella thin and joint to gonangulum forming a distinct pit. Subgenital plate triangular, approximately twice as wide as long, acute or slightly projecting beyond the middle of caudal margin (Fig. 20).

Song. The songs were recorded at $22-25^{\circ} \mathrm{C}$ in the evening and at night in the laboratory. The calling song consisted of groups of syllables containing two different types of syllables. The syllable group typically starts with one (rarely two) long syllable of 0.9-2.1 s duration and 49-74 impulses. The amplitude of these syllables increased at the beginning and decreased towards the end (Fig. 36). Sometimes an impulse series of low amplitude was observed before the main impulse group, probably an opening hemisyllable (Figs 36, 40). About 3.2 s (mean: $3.2 \mathrm{~s}$, range: $1.6-6.4 \mathrm{~s}$ ) after the typical long syllable at the beginning the song continued with a series (often about 4, range 2-22) of shorter syllables (0.4-1.1 s), all separated by intervals of 2.4-4.0 s. Part of the variability in syllable number and intervals possibly resulted from the fact that the males were not isolated, but in acoustical contact with other males and sometimes females. The syllables also had a variable amplitude pattern. Often two or three impulses were separated by a distinct gap from a longer decrescending impulse series, which, however, could also be subdivided into several groups (together 10-33 impulses) (Figs 36, 44). All these impulses and impulse groups are produced during the closing movement of the tegmina (see Heller 1990, Fig. 4B as $I$. major). When in acoustical contact with other males a male may also produce only short syllables, interspersed between the short syllables of his competitor (see Heller 1990, Fig. 4B as I. major, lowest line). Probably he tries to evoke a female respond to his own song. Females are known to respond the first short impulse group of the short syllables of an echeme (see Heller 1990, Fig. 4B, center).

Material. Holotype ô, Turkey, Mersin, Anamur, Uçarı köyü, Yelkara mevki, $36^{\circ} 6^{\prime} \mathrm{N}, 32^{\circ} 34^{\prime} \mathrm{E}, 900 \mathrm{~m}, 21 . i v .2001$ (H. Sevgili) (HUBM); paratypes $23 \sigma^{\star}$ and $22 \circ$, same data as holotype; paratypes $4 \hat{\sigma}$ (specimens no.: $\mathrm{CH} 2342-\mathrm{CH} 2344$, CH2752), 2 \% (specimens no.: CH2753, CH2754), Turkey, Mersin, Anamur $\left(36^{\circ} 4^{\prime} \mathrm{N}, 32^{\circ} 50^{\prime} \mathrm{E}\right)$, 18.vi.1987 (M. Gebhardt) $(\mathrm{CH})$.

The following previous record for I. major belong to this species: $4 \hat{\sigma}$ and $2 \%$ from Turkey, Mersin, Anamur, 18.iv.1987 (Heller, 1990).

Etymology. This new species is named after S. Salman, in recognition of his considerable contribution to our knowledge of Anatolian Orthoptera.

\section{Isophya mavromoustakisi Uvarov, 1936}

(Figs 5, 9, 13, 17, 21, 25, 29, 33, 37, 41, 45, 47-49; Tables 1, 2)

Isophya mavromoustakisi Uvarov, 1936: 508.

Isophya mavromoustakisi Uvarov, 1936: Ramme, 1951:168. Isophya mavromoustakisi Uvarov, 1936: Harz, 1969: 66. 


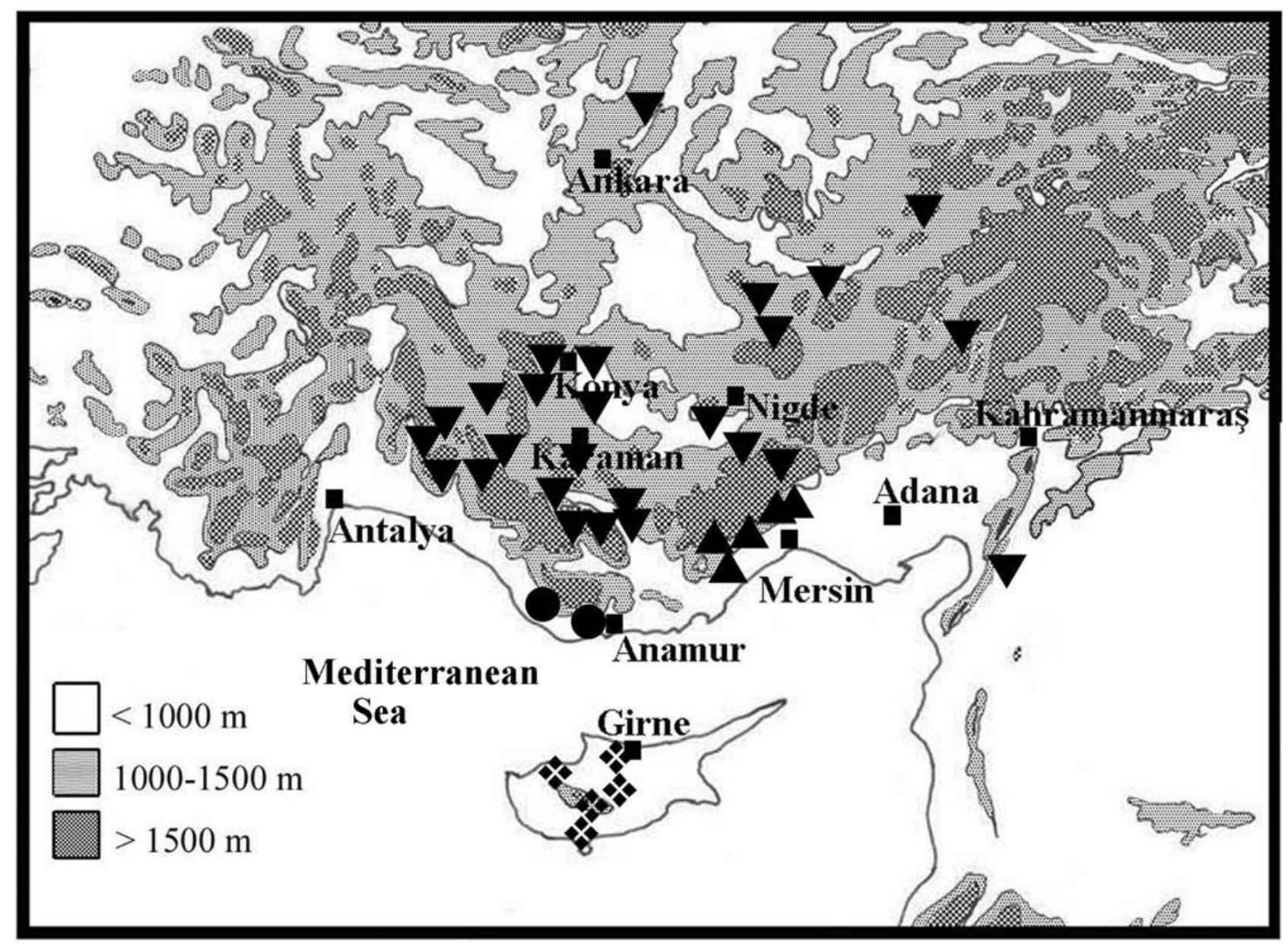

\section{I. major $\boldsymbol{\Delta}$ I. mersinensis $\bigcirc$ I. salmani $\quad$ I. mavromoustakisi}

Fig. 49. Distribution of the species of the I. major group. (Map modified from Çıplak et al., 2004.)

Isophya mavromoustakisi Uvarov, 1936: Naskrecki \& al. (OSF2, 2005)

Diagnosis. See key to species, Table 1-2 and discussion.

Redescription (male). Fastigium vertices do not extend to ridges of scapus, as wide as or narrower than half of scapus; slightly depressed dorsally, sometimes with an indistinct sulcus above.

Disk of pronotum flattened, frontal margin almost straight, caudal margin distinctly concave; lateral keels entire and thick especially on metazona, almost parallel in prozona up to transverse sulcus, strongly divergent backwards. Pronotum with dorsal margin in profile indistinctly concave; paranota with frontal margin slightly oblique, caudal margin oblique; maximum height of paranota more than half the length of pronotum (Fig. 5).

Tegmina as long as or slightly longer than pronotum, hardly extending to hind margin of second abdominal tergum, apex rounded; tegminal disc almost as long as wide, $\mathrm{Cu} 2$ of left tegmen swollen, slightly shorter than caudal margin of pronotum in length, projecting from right margin of tegmen; speculum obtusely triangular (Fig. 5). Stridulatory file $3.1 \mathrm{~mm}$, with $149-170$ pegs each gradu- ally widening towards middle and gradually narrowing towards apex (Fig. 25). Hind femur approximately 3.8 times as long as pronotum and with numerous ventral spinules especially on inner margin.

Epiproct two times as wide as long; cerci robust, gradually narrowing distalwards, distal 1/3-1/4 obtusely incurved, apex rounded, with two-three spines one of which located at apex, the other 1-2 before apex (Fig. 9). Subgenital plate distinctly tapering backwards, with indistinct lateral keels, apex with a shallow rounded incision (Fig. 17).

Female. Fastigium vertices and pronotum as in male, but dorsum of pronotum straight in profile, with an indistinct median keel on metazona (Fig. 13). Tegmina roughly quadrangular, as long as half of pronotum (Fig. 13 ); with three rows of stridulatory pegs on ventroanterior half and two-three rows of pegs on ventroposterior half (Fig. 29). Hind femur approximately 3.8 times the length of pronotum, with 3-7 spinules on both ventral margins.

Epiproct rectangular, slightly longer than basal width, slightly narrowing backwards; cerci extending sligthly beyond epiproct, slightly incurved. Ovipositor narrow and short, roughly 2.4 times as long as pronotum; gradually 
but strongly curved distalwards, with 5-7 spines on dorsal and 7-11 on ventral margin; gonangulum small with straight hind margin, lamella small and not modified (Fig. 33). Subgenital plate triangular, with obtusely rounded caudal margin (Fig. 21).

Coloration. Dirty green in general appearance. Face green or bluish-green with black spots; fastigium, vertex and scapus green with dark patterns. Pronotum with yellow lateral keels, with the area along the inner side of the keels reddish brown and outter side black; disc with a medial green stripe and black patterns (some times dark patterns weak or absent), paranota green. Tegmina hyaline green at margin, white along speculum, $\mathrm{Cu} 2$ and costal field. Legs green with dark spots. Abdomen green with two light longitudinal stripes laterally, cerci brownish-green, subgenital plate dirty green. Coloration of female similar to male; but tegmina dark green with blackish margin.

Song. The calling song, recorded at $22^{\circ} \mathrm{C}$, consisted of groups of 2-9 syllables, usually of 3-4 syllables (Figs 37, 47). These sequences were produced at quite variable intervals ( $12 \mathrm{~s}$ to $4 \mathrm{~min}, \mathrm{n}=30$ ). The whole group usually lasted about 2.3-15.5 s (mean: $6 \mathrm{~s}, \mathrm{n}=35$ ). Normally the animal started with one or two syllables containing long impulse series, which were followed by some shorter and irregular ones (Figs 41, 47). The duration of the syllables varied between 240 and $300 \mathrm{~ms}$ (syllable period 1.7-2.2 $\mathrm{s}$; mean: $2 \mathrm{~s}, \mathrm{n}=30$ ). Sometimes in the first syllable an opening hemisyllable is visible, containing 2-7 impulses then some isolated impulses fallowed by main impulse group (14-55 impulses). For the irregular syllables the mechanism of producing different impulse groups is unclear (Fig. 47c, d). The first impulse group may be either an opening hemisyllable or impulse groups are produced during the closing movement, as in I. salmani. The main impulse group was found to be broken into several shorter impulse groups of decreasing amplitude.

Material. $21 \delta^{\hat{A}}$ and $14 \%$, Turkish Republic of Northern

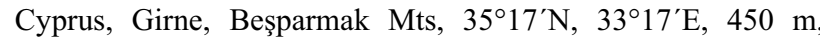
12.v.2000 (H. Sevgili) (1 $\delta^{\circ}$ and 19 in $\mathrm{CH}$, others in HUZOM); $10^{`}$, Cyprus: Lemesos, Chandria, $34^{\circ} 57^{\prime} \mathrm{N}, 32^{\circ} 59^{\prime} \mathrm{E}, 26 . i v .2001$ (K.G. Heller) $(\mathrm{CH})$.

Previous records. Holotype male and paratypes 10 and 29 , Cyprus, Amathies, 20.v.1935 (on Cytisus sp.); paratype 19 , Cyprus, Limasol, 02.v.1935; paratypes 10 , Cyprus, Kykou, 4000 feet, 02.vi.1930 (G.A. Mavromustakis) (BMNH) (Uvarov, 1936).

\section{DISCUSSION AND CONCLUSIONS}

A proper definition of the relationships of the major group with other species of Isophya requires a comprehensive phylogenetic analysis of the genus which is beyond the aim of this study. As mentioned in previous studies (e.g. Bei-Bienko, 1954; Heller et al., 2004) morphology is a poor source of taxonomic characters in this genus. However, a hind femur with spinules is one of the few reliable characters and has been used to identify species of the genus (Bei-Bienko, 1954). A hind femur with several ventral spinules is shared by the $I$. major group and a few species from the Black Sea basin, I. stepposa
Bei-Bienko, I. boldyrevi Miram, I. taurica Brunner von Wattenwyl, I. rossica Bei-Bienko (from the northern part of the Black Sea basin), I. obtusa Brunner von Wattenwyl, I. modesta Frivaldsky, I. longicaudata Ramme, I. rhodopensis (from the Balkans), I. sikorai Ramme and I. karabagi Uvarov (from Anatolia). However, species of the I. major group are easily distinguished from all of these species by the male cerci and a markedly truncate fastigium.

Uvarov (1936) and Bei-Bienko (1954) agreed that $I$. major and I. mavromoustakisi constitute a natural group sharing a male cercus with two or more denticles. A male cercus with two or more apical denticles and widened apex is also shared by the new species of the I. major group, I. salmani and I. mersinensis. It seems to be unique to the species group within the genus. In other species of Isophya, if there are two or more denticles (e.g. in I. nervosa Ramme) they are in a single line while in the I. major group not in a line, some of them located apially and other preapically.

Within the I. major group, three species other than $I$. major seem to be closely related in sharing caudally wide male tegmina and quadrangular female tegmina. Since there is no unique character shared by any couple of these species relationships between I. mavromoustakisi, I. salmani and $I$. mersinensis seem to be equivocal according to morphology. However, there are similarities that may indicate relationships. The male cercus with a single apical and few preapical (1-3) denticles is shared by $I$. mavromoustakisi and I. mersinensis, although it is also observed in some specimens of I. salmani. On the other hand, (1) a tegminal disc that is as long as wide (length/width $=1-1.1$ ) and (2) tegmina hardly longer than pronotum (tegminal/pronotal lengths $=1.1-1.2$ ) are shared by I. mavromoustakisi and I. salmani, while these two ratios are 1.3-1.5 and (1.3)1.4-1.5 respectively in $I$. major and I. mersinensis. Further, the highest number of stridulatory pegs is present in I. salmani (200-240) and the second highest in I. mavromoustakisi (149-170). Thus, from a morphological point of view, it is concluded that the relationships between species of $I$. major group appear to be I. major + (I. mersinensis + (I. salmani $+I$. mavromoustakisi).

Male calling song provides further characters to be used to define the relationships between the species of the group. A male calling song that contains two different syllable types is typical of the three species in the group other than I. major. It is probably synapomorphic to these species (see e.g. Heller et al., 2004). Of these three species, I. mersinensis shows many similarities to I. major in male calling song. Both can be separated from I. salmani and I. mavrommoustakisi by a much higher syllable repetition rate. In contrast, there are longer syllables and no sequence of syllable groups in that of I. salmani and $I$. mavromoustakisi. This may be a derived character state indicating their relationships. Therefore, song characteristics support the same phylogenetic pattern as morphology; I. major + (I. mersinensis + (I. salmani + I. mavromoustakisi) (Fig. 48). 


\section{Biogeography}

The I. major group occurs in Anatolia and Cyprus (Fig. 49). I. mavromoustakisi is endemic to Cyprus. I. salmani and I. mersinensis are local species restricted to the southern slopes of the Southern Anatolian Taurus, the first in the west and the second in the east. I. mersinensis prefers altitudes of $1000 \mathrm{~m}$ or below while I. salmani lives in lower altitudes near sea level. Adults of I. salmani occur earlier (April and may be the first half of May) than all other species, which were recorded during May and June. I. major is the most widespread species of the group. It mainly occurs in the mountains surrounding the Central Anatolian plateau, namely Southern Taurus (Adana, Mersin, Konya, Karaman and Antalya provinces of Turkey) in the south and the Anatolian Diagonal Belt (Kahramanmaraş, Nevşehir, Kayseri and Ankara provinces) in the east (for detail on Diagonal Belt see Çıplak et al., 1993).

A scenario that accounts for the distribution of the $I$. major group assumes that the ancestral stock originated in Anatolia, since the basal branches, I. major and $I$. mersinensis, are Anatolian. Additionally, possible relatives of the I. major group (e.g., I. karabagi and other species with several spinules on both ventral margins of hind femur) occur to the north of the range of this group. The most plausible explanation for the separation of the three Anatolian species (I. major, I. salmani and $I$. mersinensis) is topography depending dispersal as observed in many other Tettigoniidae (Çıplak, 2003, 2004). Although there are no clear ecological differences between the Anatolian species of the group, I. major has been recorded from northern parts of the Mediterranean and Central Anatolia where an Irano-Turanian or Mediterranean type of alpine/subalpine vegetation occurs. Additionally, this species prefers higher altitudes $I$. salmani and I. mersinensis, which were recorded from coastal areas of southern Anatolia, which have a typical Mediterranean (maquis) vegetation at low altitudes. Possibly a combination of ecological factors such as climate, altitude and vegetation mediated cladogenesis within this group.

Speciation and divergence of I. mavromoustakisi should be related to the geographic evolution of the Eastern Mediterranean. Since its sister species lives along the Mediterranean coast of Anatolia (Anamur in the western part of Mersin province), its occurrence outside Anatolia may be accounted for either by: (i) migration of the ancestral stock of I. mavromoustakisi from Anatolia to Cyprus after separation of Cyprus and Anatolia (a dispersal) or (ii) division of the range of the ancestral stock of $I$. salmani $+I$. mavromustakisi as caused by the separation of Cyprus and Anatolia (a vicariant event). There is no evidence supporting the first assumption, because these animals have reduced wings and are flightless, and the distance between the Anatolian coast and Cyprus is too long (shortest distance roughly $90 \mathrm{~km}$ ) for active transport. In addition, species of the genus Isophya lay their eggs in the soil (Can, 1959) and thus transportation of eggs is unlikely. Also, there is no evidence of their being introduced by human. The second assumption seems to be more plausible because it correlates well with the geological evolution of the Eastern Mediterranean. It has been suggested that there was a terrestrial connection between Anatolia and Cyprus during late Miocene, especially during the desiccation of the Mediterranean in the Messinian. Both lands were again isolated from each other by the beginning of the Pliocene (roughly around 5 My before present) due to reflooding of the Mediterranean (see Kempler, 1998; Robertson, 1998; Hadjisterkotis et al., 2000 for details). Thus, it is more logical to assume that I. mavromoustakisi evolved in a vicariant event from an ancestral stock that remained in Cyprus. Since there are morphological and bioacoustical differences between both species, a relatively long period of divergence can be assumed for I. mavromoustakisi and I. salmani, This situation further supports the second assumption and excludes the first.

The above assumptions allow further speculation on the separation and divergence of the whole group. Separation of the ancestral stock of the I. major group and the period of I. major and I. mersinensis diverged from the others (Fig. 38) should be before the Pliocene; the time suggested for the division of I. salmani and I. mavromoustak$i s i$. In other words, the main radiation within the major group should have begun at least in late Miocene or before. Further, I. major represents the most primitive branch within the group and the presence of a considerable amount of inraspecific variation is consistent with the above statement.

ACKNOWLEDGEMENTS. We thank S. Sevgili for rearing the nymphs at home. The study was partly supported by the Turkish Scientific Research Council (TUBITAK, TBAG-1923). This paper was supported by the Akdeniz University Research Fund (Antalya, Turkey).

\section{REFERENCES}

Bey-Bienko G.Y. 1954: Fauna of the U.S.S.R., N.S. No. 59: Orthoptera Vol. II, No. 2. Tettigonioidea, Phaneropterinae. Zoological Institute of the Academy of the Sciences of the USSR. (Israel Program for Scientific Translations, Jerusalem, 1965.) $385 \mathrm{pp}$.

BRUNNeR VON Wattenwyl C. 1878: Monographie der Phaneropteriden. Verhandlungen der Kaiserlich Königlichen Zoologisch-Botanischen Gesellschaft in Wien. Brockhaus, Wien, 401 pp., 8 pls.

CAN E. 1959: Zur Kenntnis von Isophya amplipennis Br. v. W., I. pavelii Br. v. W. und I. tenuicerca (Orth. Tettigoniidae), als Schadlinge von Eichenniederwaldern in Südosteuropa. Teil I, II. Z. Angew. Entomol. 43, 44: 387-411, 227-261.

ÇIPLAK B. 2003: Distribution of Tettigoniinae (Orthoptera, Tettigoniidae) bush-crickets in Turkey: the importance of the Anatolian Taurus Mountains in biodiversity and implications for conservation. Biodiv. Conserv. 12: 47-64.

ÇIPLAK B. 2004: Biogeography of Anatolia: marker group Orthoptera. Mem. Soc. Entomol. Ital. 82: 357-372.

Çiplak B., Demirsoy A. \& BozcuK A.N. 1993: Distribution of Orthoptera in relation to the Anatolian Diagonal in Turkey. Articulata 8: 1-20.

Çiplak B., Demirsoy A., Yalim B. \& Sevgili H. 2002: Türkiye Orthoptera (Düzkanatlılar, Çekirgeler) Faunası. In Demirsoy 
A. (ed.): Genel Zoocoğrafya ve Türkiye Zoocoğrafyası. Meteksan Yayınları, Ankara, pp. 681-707.

Hadisterkotis E., Masala B. \& Reese D.S. 2000: The origin and extinction of the large endemic Pleistocene mammals of Cyprus. Biogeographie 21: 593-606.

HARZ K. 1963: Eine Unterart von Isophya maior Br. W. im Taurus. Ber. Naturwiss. Ges. Bayreuth 11: 165-167.

Harz K. 1969: The Orthoptera of Europe. Vol. 1. Dr. W. Junk, The Hague, 749 pp.

Heller K.G. 1988: Bioakustik der europäischen Laubheuschrecken. J. Margraf, Weikersheim, 360 pp.

HeLler K.G. 1990: Evolution and song pattern in Eastern Mediterranean Phaneropterinae: Constrains by the communication system. In Bailey W.J \& Rentz D.C.F. (eds): The Tettigoniidae: Biology, Systematics and Evolution. Crawford House Press, Bathurst, pp. 130-151.

Heller K.G., Korsunovskaya O., Ragge D.R., Vedenina V., Willemse F., Zhantiev R.D. \& Frantsevich L. 1998: Checklist of European Orthoptera. Articulata 7: 1-61.

Heller K.G., Orci K.M., Grein G. \& Ingrisch S. 2004: The Isophya species of central and western Europe (Orthoptera: Tettigonioidea: Phaneropteridae). Tijdschr. Entomol. 147: $237-258$.

Howard D.J. \& Berlocher S.H. (eds) 1998: Endless Forms. Species and Speciation. Oxford University Press, Oxford, 470 pp.

INGRISCH S. 1991: Taxonomie der Isophya-Arten der Ostalpen (Grylloptera: Phaneropteridae). Mitt. Schweiz. Entomol. Ges. 64: 269-280.

KARABAĞ T. 1958: Türkiye'nin Orthoptera faunast. [A Synonymic and Distributional Calalogue of Turkish Orthoptera.] Ankara Üniversitesi Fen Fakültesi Yayınları Umumi: 81, Zooloji 4. Ankara, 198 pp. [in Turkish and English].

KARABAĞ T. 1964: Some new species and new records of Tettigoniidae (Orthoptera) from Turkey. Communications 13: 36-55.

Karabaŭ T., Balamir S., Gümüșsuyu İ. \& Tutkun E. 1981: Türkiye Orthoptera faunasının tesbiti üzerine araștırmalar. Bitki Koruma Bült. 20: 1-25.

KEMPLER D. 1998: Eratosthenes seamount: the possible spearhead of incipient continental collision in the Eastern Mediterranean. In Robertson A.H.F., Emeis K.C., Richter C. \& Camerlanghi A. (eds): Proceedings of the Ocean Drilling Programm, Scientific Results, Vol. 160. Collage Station, TX (Ocean Drilling Program), pp. 709-721.

LA GRECA M. 1999: Il contributo degli Ortotteri (Insecta) alla conoscenza della biogeografia dell' Anatolia: la componente gondwaniana. Biogeographia 20: 179-200.

MǍ̌AN J. 1958: Wissenschaftliche Ergebnisse der zoologischen Expedition des Nationalmuseums in Prag nach der Turkei. 23.
Orthoptera - Tettigoniidae - Gattung Isophya Br. W. Acta Entomol. Mus. Nat. Pragae 32: 285-293.

Naskrecki P. \& Ünal M. 1995: The Orthoptera of Hatay Province, S. Turkey. Beitr. Entomol. 45: 393-419.

Naskrecki P., Otte D. \& Eades D. 2005: Orthoptera Species File Online Version 2 (OSF). http://osf2.orthoptera.org/basic/ hierarchy.asp and http:/www.tettigonia.com (February, 2005).

OrCi K.M., SzÖVEnYI G. \& NaGY B. 2001: Description of the song of Isophya beybienkoi (Orthoptera, Tettigonioidea). Biologia 56: 489-495.

RagGe D.R. \& Reynolds W.J. 1998: The Songs of the Grasshoppers and Crickets of Western Europe. Harley Books, London, $221 \mathrm{pp}$.

RoBERTSON A.H.F. 1998: Mesozoic-Tertiary tectonic evolution of the Eratosthenes Mediterranean area: integration of marine and land evidence. In Robertson A.H.F., Emeis K.C., Richter C. \& Camerlanghi A. (eds): Proceedings of the Ocean Drilling Programm, Scientific Results, Vol. 160. Collage Station, TX (Ocean Drilling Program), pp. 723-782.

Ramme W. 1951: Zur Systematik, Faunistik und Biologie der Orthopteren von Südost-Europa und Vorderasien. Mitt. Zool. Mus. Berlin 27: 1-421.

SeVGiLi H. 2003: A new species of bushcricket (Orthoptera: Tettigoniidae) of the palaearctic genus Isophya (Phaneropterinae) from Turkey. Entomol. News 114(4):129-137.

Sevgili H. \& Heller K.G. 2003: A new species of the genus Isophya Brunner von Wattenwyl from Turkey (Orthoptera, Tettigoniidae, Phaneropterinae). Tijdschr. Entomol. 146: 39-44.

Uvarov B.P. 1936: New Orthoptera from Cyprus. Ann. Mag. Nat. Hist. 18: 505-515.

ÜNAL M. 1997: Nevşehir ili Avanos çevresinin Orthopterlerinin eko-faunası üzerine araştırmalar. Priamus 9(1): 1-54.

ÜNAL M. 1999: Notes on Orthoptera of Western Turkey, with description of a new genus and four new species. J. Orthoptera Res. 8: 243-255.

ÜNAL M. 2004: Distribution of fourty-six species of the genera Isophya Brunner von Wattenwyl, Poecilimon Fischer and Poecilimonella Uvarov (Orthoptera: Tettigoniidae: Phaneropterinae) in Turkey with description of two new species. Priamus 11(1/2): 1-16.

Wheeler Q.D. \& Meier R. (eds) 2000: Species Concepts and Phylogenetic Theory: A Debate. Columbia University Press, New York, 229 pp.

WeRNER F. 1901: Die Dermapteren- und Orthopterenfauna Kleinasiens. Sitzungsber. Akad. Wissenschaft. Wien 110: 259-305.

Received May 3, 2005; revised and accepted February 2, 2006 